\title{
MACAM MEDIA KOMUNIKASI PEMASARAN BERAS PANDANWANGI DAN PENYAMPAIAN TERHADAP TINGKAT EFEKTIVITAS KOMUNIKASI PEMASARAN DI CIANJUR (STUDI KASUS KOPERASI KESEJAHTERAAN UNSUR, CV PURE, PB SINDANG ASIH, PB OKH DAN TOKO PRIBADI)
}

\author{
Oleh: \\ Endah Lisarini**) \\ Yuni Siti Rachmayanti*)
}

\begin{abstract}
Abstrak
Komunikasi pemasaran adalah sarana dimana perusahaan berusaha menginformasikan, membujuk, dan meningkatkan konsumen secara langsung maupun tidak langsung tentang produk dan merek yang dijual. Untuk membangun suatu komunikasi melalui media komunikasi pemasaran beras yang dipasarkan khususnya beras Pandanwangi semakin dikenal oleh masyarakat luas. Perlu diperhatikan efektifitasnya melalui media komunikasi pemasaran dimana perusahaan berharap dengan strategi yang digunakannya tersebut dapat menciptakan hubungan komunikasi yang efektif dalam rangka mempromosikan produk kepada konsumen. Penelitian ini bertujun untuk mengetahui media komunikasi pemasaran yang banyak direspon dalam menyampaikan informasi dan untuk mengetahui tingkat efeketivitas dari media komunikasi pemasaran yang banyak digunakan oleh penjual beras Pandanwangi. Penelitian ini dilaksanakan di wilayah pemasaran kecamatan Cianjur sejak bulan Mei sampai dengan bulan Juli 2019. Metode analisis yang digunakan adalah deksriptif kuantitatif dengan indikator AIDA . Hasil analisis penelitian menunjukkan bahwa media komunikasi pemasaran paling banyak direspon yaitu media komunikasi pemasaran langsung termasuk kategori setuju sebesar 4,10 (3,41-4,20). Sementara media komunikasi yang paling efektif adalah media komunikasi pemasaran berupa iklan.
\end{abstract}

Kata kunci : Media, Pemasaran, Pandanwangi, Efektivitas

\section{Abstract}

Marketing communication is a means by which companies try to inform, persuade, and improve consumers directly or indirectly about the products and brands that are sold. To develop a communication through marketing marketing communication media, especially Pandanwangi rice, is increasingly recognized by the wider community. It is important to note its effectiveness through marketing communication media where the company hopes that the strategy it uses can create effective communication relationships in order to promote products to consumers. This study aims to determine the marketing communications media that are widely responded in conveying information and to determine the level of effectiveness of marketing communication media that are widely used by Pandanwangi rice sellers. This research was conducted in the marketing area of Cianjur sub-district from May to July 2019. The analytical method used was quantitative descriptive with AIDA indicators. The results of the research analysis showed that the most widely responded marketing communication media were direct marketing communication media including the agreed category of

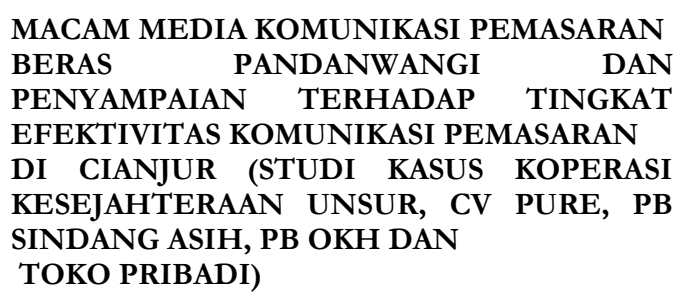


4.10 (3.41-4.20). While the most effective communication media was marketing communication media in the form of advertisements.

Keywords: Media, Marketing, Pandanwangi, Effectiveness.

*) Alumni Fakultas Sains Terapan UNSUR

**) Dosen Fakultas Sains Terapan UNSUR 


\section{PENDAHULUAN}

Dalam era modern ini perkembangan teknologi semakin pesat dengan banyaknya bermunculan sarana komunikasi yang semakin mutakhir (Sufa,2012). Hal ini berkaitan dengan pandangan baru tentang komunikasi sebagai dialog interaktif antara produsen dan konsumen yang berlangsung selama tahap promosi, penjualan, dan pasca penjualan, agar pelanggan dapat menjangkau produk yang dipasarkan (Kotler,2003). Promosi sebagai sebuah strategi pemasaran juga semakin berpacu menghadapi perkembangan globalisasi.

Menurut hasil observasi dilapangan Tahun 2018 tidak dipublikasikan, Media komunikasi pemasaran beras Pandanwangi di CV Pure Cianjur antara lain Periklanan (advertising) ,Promosi Penjualan (Sales Promotion) Penjualan Perorangan (Personal Selling) Sebagai perusahaan yang memasarkan produk beras Pandanwangi, CV Pure Cianjur banyak mengandalkan personal selling atau penjualan perorangan karena lebih mudah memberikan informasi yang lengkap kepada konsumen. Sehingga komunikasi yang dibangun melalui penjualan perorangan jauh lebih dapat memahami apa keinginan dari konsumen.

Personal selling itu sendiri dilakukan oleh CV Pure Cianjur guna menarik minat beli calon konsumen untuk membeli produk yang ditawarkan agar dapat meningkatkan penjualan. karena Personal selling dapat menghasilkan komunikasi dua arah melalui kegiatan tatap muka dengan calon konsumen. Kegiatan personal selling yang dilakukan oleh CV Pure Cianjur yaitu menjual ke karyawan Dinas Pertanian Kabupaten Cianjur, penikmat beras organic, dan masyarakat yang penasaran dengan cita rasa beras istimewa seperti beras Pandanwangi yang menjadi salah satu kearifan lokal Cianjur.

Marketing event dilakukan melalui pameran-pameran dan bazar-bazar yang diikutinya. Kegiatan mengkomunikasikan mulut ke mulut ini dilakukan oleh beberapa customer CV Pure Cianjur yang sudah merasa puas terhadap produk CV Pure. Perkembangan teknologi informasi (internet) memberikan dampak terhadap penjualan produk. Proses penjualan konvensional menuntut pertemuan antara produsen dan kosnsumen secara langsung. Pertemuan tersebut terjadi pada sebuah tempat yang dinamakan pasar.Namun sekarang ini ,proses tersebut tidak selalu menuntut pertemuan langsung karena transaksi yang dilakukan dapat menggunakan media internet. CV Pure Cianjur memasarkan produknya melalui Facebook, Whatsapp dan Instagram sebagai sarana media pemasarannya agar mempermudah dalam memasarkan produkya.

Komunikasi pemasaran adalah cara yang digunakan perusahaan untuk menginformasikan, mempersuasi, dan mengingatkan konsumen, baik secara langsung maupun tidak langsung mengenai produk dan merek yang mereka jual. Komunikasi pemasaran berkontribusi terhadap ekuitas merek dengan membangun merek dalam ingatan (brand awareness) dan menciptakan citra merek (brand image) yang mencakup enam komponen yaitu periklanan, promosi penjualan, event, public relations dan publisitas, pemasaran langsung, dan penjualan personal (Kotler\& Keller, 2006).

Kennedy (2006 ) komunikasi pemasaran juga dapat dinyatakan sebagai kegiatan komunikasi yang bertujuan untuk menyampaikan pesan pada konsumen dengan menggunakan berbagai media, dengan harapan agar komunikasi dapat menghasilkan tiga tahap perubahan, yaitu perubahan pengetahuan, perubahan sikap, dan perubahan tindakan yang dikehendaki. Perubahan pengetahuan adalah tahapan paling awal dari sebuah proses komunikasi yang termasuk kedalam efek kognitif yaitu tahapan 
awareness (kesadaran) akan keberadaan suatu hal. Dari penjelasan berbagai teori komunikasi pemasaran diatas, disimpulkan bahwa komunikasi pemasaran dan brand awareness memiliki kaitan yang erat. Dimana dari komunikasi pemasaran yang dilakukan oleh sebuah perusahaan maka akan mempengaruhi brand awareness dari perusahaan itu sendiri. Strategi Komunikasi Pemasaran Perencanaan strategi komunikasi pemasaran meliputi sejumlah strategi pesan dan visual, yang secara bertahap mengikuti alur perubahan, yang kemudian harus diukur secara tepat melalui riset komunikasi pemasaran.

Dalam mengembangkan komunikasi pemasaran yang efektif, ada delapan tahapan yang harus dilalui, yaitu Mengidentifikasi audiens sasaran, Menentukan tujuan komunikasi, Merancang pesan, Memilih saluran komunikasi, Menetapkan total anggaran komunikasi, Menentukan bauran promosi, Mengukur hasil promosi, Mengelola dan mengkoordinasikan proses komunikasi (Sulaksana, 2003).

Komunikasi pemasaran dapat didefinisikan sebagai kegiatan komunikasi yang dilakukan oleh pembeli dan penjual, dan merupakan kegiatan yang membantu dalam pengambilan keputusan dalam bidang pemasaran serta mengarahkan pertukaran agar lebih memuaskan dengan cara menyadarkan semua pihak untuk berbuat lebih baik (Swastha, 2009).

Media massa merupakan alat yang digunakan untuk menyampaikan pesan kepada khalayak,dimana karakteristik media massa yang digunakan berbedabeda membuat perusahaan harus cermat dalam memilih media massa seperti apa yang paling tepat digunakan untuk mempromosikan perusahaannya guna mendapat profit. Hal ini menjadi landasan pentingnya mempelajari karakteristik berbagai media massa khususnya pada hal periklanan agar perusahaan dapat menentukan media massa jenis seperti apa yag paling efektif untuk digunakan.

Begitupun dengan media komunikasi pemasaran yang saat ini banyak digunakan oleh banyak perusahaan untuk memperkenalkan produknya di berbagai macam media agar menarik minat konsumen. Dan tidak lepas dari peraturan perundang-undangan yang dimana di dalamnya terdapat aturan yang harus dipatuhi.

Undang-undang Informasi dan Transaksi Elektronik (UU ITE) adalah ketentuan yang berlaku untuk setiap orang yang melakukan perbuatan hukum sebagaimana diatur dalam UndangUndang ini, baik yang berada di wilayah hukum Indonesia maupun di luar wilayah hukum Indonesia, yang memiliki akibat hukum di wilayah hukum Indonesia dan/atau di luar wilayah hukum Indonesia dan merugikan kepentingan Indonesia.

Undang-Undang Nomor 11 Tahun 2008 tentang Informasi dan Transaksi Elektronik ("UU ITE") telah diatur adanya konten-konten yang dilarang untuk didistribusikan, ditransmisikan, atau dibuat dapat diakses. Misalnya:

\section{Pasal 27 UU ITE:}

(1) Setiap Orang dengan sengaja dan tanpa hak mendistribusikan dan/atau mentransmisikan dan/atau membuat dapat diaksesnya Informasi Elektronik dan/atau Dokumen Elektronik yang memiliki muatan yang melanggar kesusilaan.

(2) Setiap Orang dengan sengaja dan tanpa hak mendistribusikan dan/atau mentransmisikan dan/atau membuat dapat diaksesnya Informasi Elektronik dan/atau Dokumen Elektronik yang memiliki muatan perjudian.

Undang-Undang Republik Indonesia No. 8 Tahun 1999 Tentang Perlindungan Konsumen

Pasal 9 
1. Pelaku usaha dilarang menawarkan, mempromosikan, mengiklankan suatu barang dan/atau jasa secara tidak benar, dan atau seolah-olah:

a. Barang tersebut telah memenuhi dan/atau memiliki potongan harga, harga khusus, standar mutu tertentu, gaya atau mode tertentu, karakteristik tertentu, sejarah atau guna tertentu;

b. Barang tersebut dalam keadaan baik dan/atau baru;

c. Barang dan/atau jasa tersebut telah mendapatkan dan/atau memiliki sponsor, persetujuan, perlengkapan tertentu, keuntungan tertentu, ciriciri kerja atau aksesori tertentu;

d. Barang dan/atau jasa tersebut dibuat oleh perusahaan yang mempunyai sponsor, persetujuan atau afiliasi;

e. Barang dan/atau jasa tersebut tersedia;

f. Barang tersebut tidak mengandung cacat tersembunyi;

g. Barang tersebut merupakan kelengkapan dari barang tertentu;

h. Barang tersebut berasal dari daerah tertentu;

i. Secara langsung atau tidak langsung merendahkan barang dan/atau jasa lain;

j. Menggunakan kata-kata yang berlebihan, seperti aman, tidak berbahaya, tidak mengandung resiko atau efek sampingan tanpa keterengan yang lengkap;

k. Mengandung sesuatu yang mengandung janji yang belum pasti.

Dalam Butir 4.5.1 EPI diatur mengenai etika iklan pada media internet yaitu bahwa iklan tidak boleh ditampilkan sedemikian rupa sehingga mengganggu kebisaan atau keleluasaan khalayak untuk merambah (to browse) dan berinteraksi dengan situs terkait, kecuali telah diberi peringatan sebelumnya. Konsep ini dapat dijadikan acuan dalam pengiklanan produk melalui jaringan telekomunikasi.
Untuk membangun suatu komunikasi melalui media komunikasi pemasaran beras yang dipasarkan khususnya beras Pandanwangi semakin dikenal oleh mayarakat luas. CV Pure Cianjur membangun komunikasi melalui media komunikasi pemasaran dimana perusahaan berharap dengan strategi yang digunakannya tersebut dapat menciptakan hubungan komunikasi yang efektif dalam rangka mempromosikan produk kepada konsumen.

Berdasarkan penjelasan di atas, penulis tertarik untuk melakukan penelitian mengenai " Macam Media Komunikasi Pemasaran Beras Pandanwangi dan Penyampaian Terhadap Tingkat Efektivitas Komunikasi Pemasaran di Cianjur (Studi Kasus CV Pure, Koperasi Kesejahteraan UNSUR, PB Sindang Asih, PB OKH, Dan Toko Pribadi)"

\section{METODE PENELITIAN}

\section{Tempat dan Waktu}

Penelitian dilakukan di wilayah pemasaran kecamatan Cianjur. Penelitian ini dilakukan di CV Pure, Koperasi Kesejahteraan UNSUR, PB Sindang Asih, PB OKH dan Toko Pribadi. Pelaksanaan penelitian ini dilakukan pada bulan Mei 2019 sampai dengan bulan Juli 2019.

\section{Variabel Penelitian}

Menurut Sugiyono (2012), variabel penelitian merupakan suatu atribut atau sifat yang dapat dijadikan nilai dari orang, objek ataupun kegiatan yang mempunyai variasi tertentu yang ditetapkan oleh peneliti untuk dipelajari dan dapat ditarik sebuah kesimpulannya. Dalam penelitian ini yang menjadi variabel penelitian adalah media komunikasi pemasaran seperti periklanan, penjualan perseorangan, publisitas, promosi penjualan dan pemasaran langsung. 
Tabel 1. Variabel Penelitian.

\begin{tabular}{|c|c|c|c|}
\hline $\begin{array}{c}\text { Variabel } \\
\text { Penelitian }\end{array}$ & Konsep Variabel & Indikator & Skala \\
\hline Periklanan & $\begin{array}{l}\text { Periklanan (advertising) adalah pesan yang } \\
\text { menawarkan suatu produk yang ditujukan } \\
\text { kepada masyarakat lewat suatu media. } \\
\text { (Khasali , 2007). Efektivitas media } \\
\text { promosi produk dapat diukur dengan } \\
\text { menggunakan model AIDA yaitu attention } \\
\text { (perhatian),interest (ketertarikan), desire } \\
\text { (keinginan),dan action (tindakan). }\end{array}$ & $\begin{array}{l}\text { 1. Memberikan } \\
\text { perhatian } \\
\text { 2. Memberi ketertarikan } \\
\text { 3. Keinginan } \\
\text { 4. Mengambil } \\
\text { keputusan dalam } \\
\text { melakukan pembelian }\end{array}$ & Ordinal \\
\hline $\begin{array}{l}\text { Penjualan } \\
\text { perseorangan }\end{array}$ & $\begin{array}{l}\text { Penjualan perseorangan adalah komunikasi } \\
\text { langsung (tatap muka) antara penjual dan } \\
\text { calon pelanggan untuk memperkenalkan } \\
\text { suatu produk. (Tjiptono, 2008). Efektivitas } \\
\text { media promosi produk dapat diukur } \\
\text { dengan menggunakan model AIDA yaitu } \\
\text { attention (perhatian),interest (ketertarikan), } \\
\text { desire (keinginan), dan action (tindakan). }\end{array}$ & $\begin{array}{l}\text { 1. Memberikan } \\
\text { perhatian } \\
\text { 2. Memberi ketertarikan } \\
\text { 3. Keinginan } \\
\text { 4. Mengambil } \\
\text { keputusan dalam } \\
\text { melakukan pembelian }\end{array}$ & Ordinal \\
\hline Publisitas & $\begin{array}{l}\text { Publisitas adalah suatu cara berkomunikasi } \\
\text { dalam bentuk berita mengenai suatu } \\
\text { organisasi, produk(Budiarto, 2011) } \\
\text { Efektivitas media promosi dapat diukur } \\
\text { dengan menggunakan model AIDA yaitu } \\
\text { attention (perhatian),interest (ketertarikan), } \\
\text { desire (keinginan),dan action (tindakan). }\end{array}$ & $\begin{array}{l}\text { 1. Memberikan } \\
\text { perhatian } \\
\text { 2. Memberi ketertarikan } \\
\text { 3. Keinginan } \\
\text { 4. Mengambil } \\
\text { keputusan dalam } \\
\text { melakukan pembelian }\end{array}$ & Ordinal \\
\hline $\begin{array}{l}\text { Promosi } \\
\text { penjualan }\end{array}$ & $\begin{array}{l}\text { Kegiatan promosi untuk melakukan } \\
\text { rangsangan kepada konsumen untuk } \\
\text { melakukan pembelian. (Rangkuti, 2009). } \\
\text { Efektivitas media promosi dapat diukur } \\
\text { dengan menggunakan model AIDA yaitu } \\
\text { attention (perhatian),interest (ketertarikan), } \\
\text { desire (keinginan),dan action (tindakan). }\end{array}$ & $\begin{array}{l}\text { 1. Memberikan } \\
\text { perhatian } \\
\text { 2. Memberi ketertarikan } \\
\text { 3. Keinginan } \\
\text { 4. Mengambil } \\
\text { keputusan dalam } \\
\text { melakukan pembelian }\end{array}$ & Ordinal \\
\hline $\begin{array}{l}\text { Pemasaran } \\
\text { langsung }\end{array}$ & $\begin{array}{l}\text { Direct marketing merupakan cara promosi } \\
\text { yang menggunakan media yang dapat } \\
\text { menghubungkan secara langsung marketers } \\
\text { dengan konsumen,,sehingga respon dari } \\
\text { konsumen dapat langsung diterima. Jenis } \\
\text { media itu disebut sebagai direct response } \\
\text { media (Belch \& Belch, 2004) }\end{array}$ & $\begin{array}{l}\text { 1. Memberikan } \\
\text { perhatian } \\
\text { 2. Memberi ketertarikan } \\
\text { 3. Keinginan } \\
\text { 4. Mengambil } \\
\text { keputusan dalam } \\
\text { melakukan pembelian }\end{array}$ & Ordinal \\
\hline
\end{tabular}

\section{Metode Analisis}

\section{Analisis Deskriptif}

Untuk menjawab tujuan penelitian pertama, peneliti menggunakan analisis deskriptif. Penelitian deskriptif adalah penelitian yang bertujuan untuk menjelaskan atau mendeskripsikan suatu keadaan, peristiwa, objek apakah orang, atau segala sesuatu yang terkait dengan variabel-variabel yang bisa dijelaskan baik dengan angka-angka maupun kata-kata
(Sukmadinata, 2006; Syah, 2010; Setyosari, 2010).

\section{Analisis Kuantitatif}

Untuk menjawab tujuan penelitian ke dua, peneliti menggunakan analisis kuantitatif dengan menghitung skor rata-rata tanggapan responden terhadap efektivitas semua media komunikasi pemasaran yang digunakan oleh para penjual beras Pandanwangi. Metode kuantitatif adalah

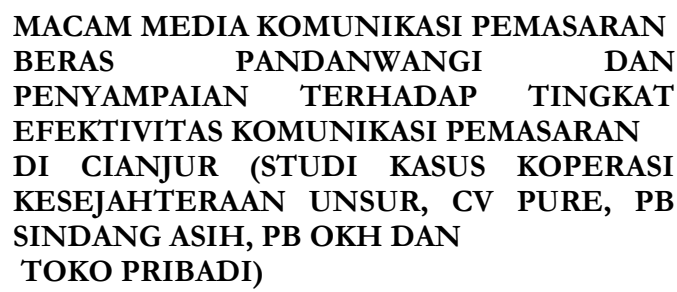


Metode penelitian yang berdasarkan pada filsafat positivisme, digunakan untuk meneliti pada populasi suatu sampel tertentu, teknik pengambilan sampel pada umumnya random, pengumpulan data menggunakan instrument penelitian, analisis data bersifat kuantitatif atau statistic dengan tujuan untuk menguji hipotesis yang telah ditetapkan. (Sugiyono, 2014).

Nilai rata-rata responden dimasukkan ke dalam kelas interval, dimana rumus yang digunakan menurut Sudjana (2008) dalam Nasir (2017) adalah : Interval kelas $=\underline{\text { nilai tertinggi }- \text { nilai terendah }}$ jumlab kelas
Keterangan : nilai tertinggi $=5$ nilai terendah $=1$ jumlah kelas $=5$ Interval nilai $=5-1 /$ jumlah

kelas $=4-5=0,8$

Dari rumus tersebut diperoleh besarnya kelas interval adalah 0,8 .

Data yang terhitung yaitu skor nilai dibagi jumlah respoden hasil yang diperoleh dibandingkan degan kategori nilai interval yaitu : (1) Sangat tidak setuju, (2) Tidak setuju, (3) Cukup setuju, (4) Setuju, (5) Sangat Setuju.

Kategori nilai interval yaitu sebagai berikut:

Tabel 2. Kategori Nilai Interval.

\begin{tabular}{cc}
\hline Nilai Interval & Kategori \\
\hline $1,00-1,80$ & Sangat tidak setuju \\
$1,81-2,60$ & Kurang setuju \\
$2,61-3,40$ & Cukup setuju \\
$3,41-4,20$ & Setuju \\
$4,21-5,00$ & Sangat setuju \\
\hline
\end{tabular}

Tingkat efektivitas setiap media komunikasi pemasaran akan ditentukan melalui skor tertinggi di setiap media komunikasi.

\section{Perangkingan Nilai Skor Rata-rata}

Untuk menentukan perangkingan nilai skor rata-rata, rangking ditentukan dengan cara mengurutkan nilai skor responden dari nilai tertinggi sampai nilai terendah.

\section{HASIL DAN PEMBAHASAN}

\section{Gambaran Umum Penjual Beras Pandanwangi}

\section{CV Pure Cianjur}

CV Pure Cianjur diketuai oleh Siti Chodidjah Ma'sum SP dengan sekertaris Empat Kurniawati, A.Md dan bendahara yaitu Sarah Siti Sumaerah. CV Pure Cianjur telah terdaftar sebagai perusahaan dengan nomor 10.06.3.51.02868 yang diperoleh dari Badan Pelayanan Perizinan Terpadu dan Penanaman Modal Kabupaten Cianjur. CV Pure Cianjur berlokasi di Perumahan Gading Asri, Jl. Cendana Blok No.31, RT 01 RW17, Desa Bojong, Kecamatan Karangtengah, Kabupaten Cianjur. Lokasi tersebut terletak di rumah Ibu Siti Chodidjah. CV Pure Cianjur buka setiap hari Senin sampai dengan Minggu kecuali libur nasional, mulai pukul 08.00 WIB sampai dengan pukul 16.00 WIB.

CV Pure Cianjur yang awalnya bernama Beras Cianjur "Berasku" Pure Cianjur didirikan oleh Ibu Siti Chodidjah Ma'sum selaku ketua pada tanggal 04 september 2014 yang sudah dirintis sejak 04 September 2011. Pada tanggal 15 Februari 2016, unit usaha ini telah berbadan hukum menjadi Perseroan Komanditer (CV) menjadi CV Pure Cianjur.

Berawal terbentuknya CV Pure Cianjur ketika Ibu Siti Chodidjah sebagai penyuluh pertanian yang membina Kelompok Tani Bangkit untuk meningkatkan produktivitas padi Pandanwangi yang menjadi salah satu 
kearifan lokal Cianjur. Pada saat itu, Dinas Pertanian Kabupaten Cianjur tempat Ibu Siti Chodidjah bekerja hanya membina untuk meningkatkan produksi padi Pandanwangi saja, sehingga para petani Kelompok Tani Bangkit kebingungan dengan pemasaran padi dan beras Pandanwangi yang telah dihasilkan. Pada tahun 2011, Ibu Siti Chodidjah mulai membantu pemasaran beras Pandanwangi. Beras Produk hasil dari Kelompok Tani Bangkit mulai dipasarkan oleh Ibu Siti Chodidjah melalui pameranpameran dan bazar-bazar yang diikutinya. Pemasaran pun didukung oleh pihak Dinas Pertanian dan Tanaman Pangan Kabupaten Cianjur. Beras Pandanwangi tersebut mulai dipasarkan dengan nama "Beras Cianjur "Berasku".

Pada Tahun 2014 di salah satu pameran yang diadakan di Gedung Sate Bandung, produk Beras Cianjur "Berasku" menarik minat dan dilirik serta

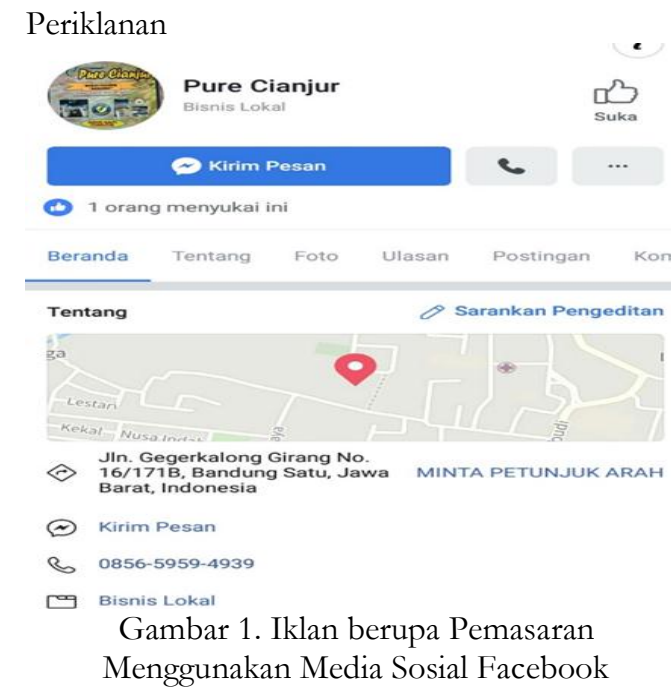

diberikan penawaran untuk dijual di perusahaan ritel Carrefour untuk wilayah Jawa Barat. Penawaran tersebut merupakan sebuah kesempatan awal bagi perkembangan CV Pure Cianjur.

Hingga saat ini CV Pure Cianjur telah mengalami banyak pengembangan usaha, mulai dari segi produk, kepemilikan asset, tenaga kerja, sistem jual beli beras dan lain-lain. Salah satu pengembangan yang telah dilakukan oleh CV Pure Cianjur dengan memiliki berbagai Sertifikat PIRT dengan nomor 2153203011083-19, Sertifikat Halal, Sertifikat Organik dan Sertifikat Indikasi Geodrafis (SIG) untuk meningkatkan daya saing beras Pandanwangi Cianjur yang mengalami penurunan output karena maraknya pengoplosan dan pemakaian pewangi yang telah beredar di pasaran.

Media komunikasi pemasaran yang telah digunakan olah CV Pure Cianjur di antaranya :

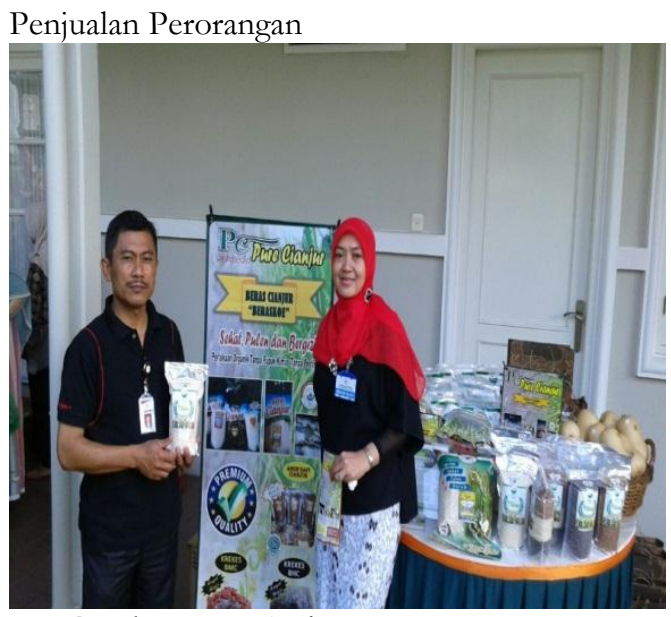

Gambar 2. Penjualan Perseorangan yang dilakukan oleh pemilik CV Pure Cianjur 


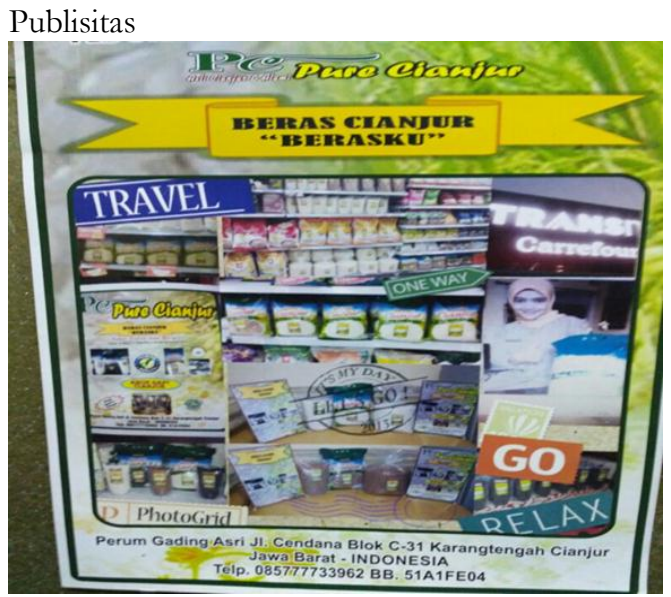

Gambar 3. berupa brosur CV Pure Cianjur.
Promosi Penjualan

\begin{tabular}{|c|c|c|}
\hline \multirow{2}{*}{  } & $\begin{array}{l}\text { BELANJA APA SAJA DI } \\
\text { TRANSMART }\end{array}$ & \multirow{2}{*}{$\begin{array}{l}\text { MENGGUNAKAN SEMUA JenIS } \\
\text { KARTU DEBIT } \\
\text { ВANK MEGA }\end{array}$} \\
\hline & Carrefour $(\boldsymbol{)}$ & \\
\hline
\end{tabular}

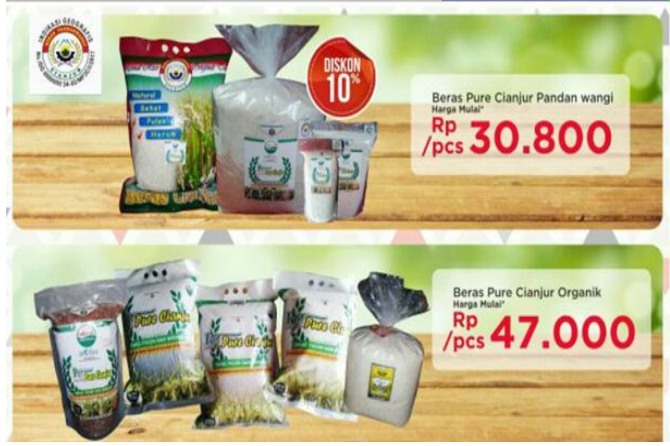

Gambar 4. Kegiatan Promosi sekaligus memperkenalkan produk CV Pure Cianjur

Pemasaran Langsung
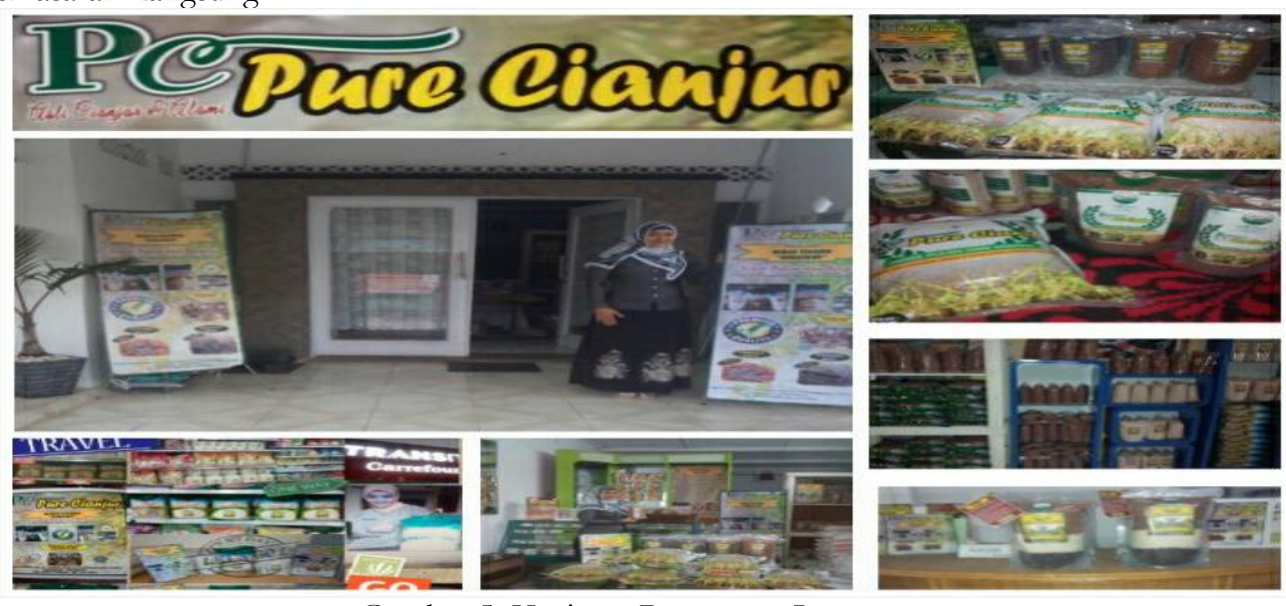

Gambar 5. Kegiatan Pemasaran Langsung.

\section{Koperasi Kesejahteraan UNSUR}

Koperasi Kesejahteraan UNSUR berdiri sejak April 2014, diketuai oleh Dr. dr. Hj. Trini Handayani, S.H, M.H , beralamat di Jl. Pasir Gede Raya Cianjur. Koperasi Kesejahteraan UNSUR telah menjual beras Pandanwangi 1 tahun terakhir dan telah mendapat izin rekomendasi penggunaan logo sertifikat indikasi geografis beras Pandanwangi yang telah terdaftar di MP3C.

Visi :

Terwujudnya Pelayanan yang Optimal untuk Peningkatan Kesejahteraan Anggota Koperasi Universitas Suryakancana secara Syar’i
Misi :

1. Meningkatkan Profesionalisme Pengelola Koperasi Kesejahteraan Universitas Suryakancana (Pengurus,Pengawas dan Karyawan)

2. Meningkatkan Kualitas Manajemen dan Tata Kelola yang Transaparan dan Akuntabel

3. Meningkatkan Partisipasi Aktif Anggota Koperasi Kesejahteraan Universitas Suryakancana Sebagai Pemilik Koperasi

4. Meningkatkan Partisipasi Aktif Anggota Koperasi Kesejahteraan Universitas Suryakancana sebagai Pengguna Jasa Koperasi

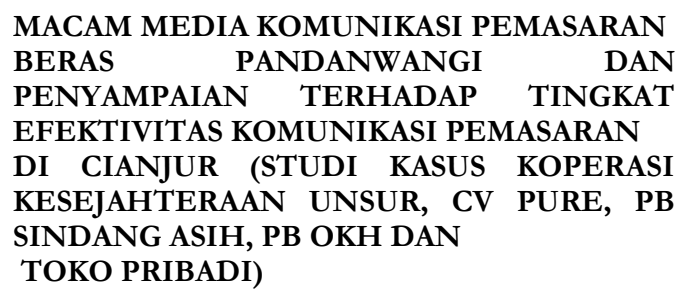


5. Mengoptimalkan Sumber Daya yang ada untuk meningkatkan Pelayanan dan Usaha Koperasi Kesejahteraan Universitas Suryakancana

6. Melakukan Kerjasama Usaha yang saling menguntungkan dalam rangka Pengembangan Koperasi

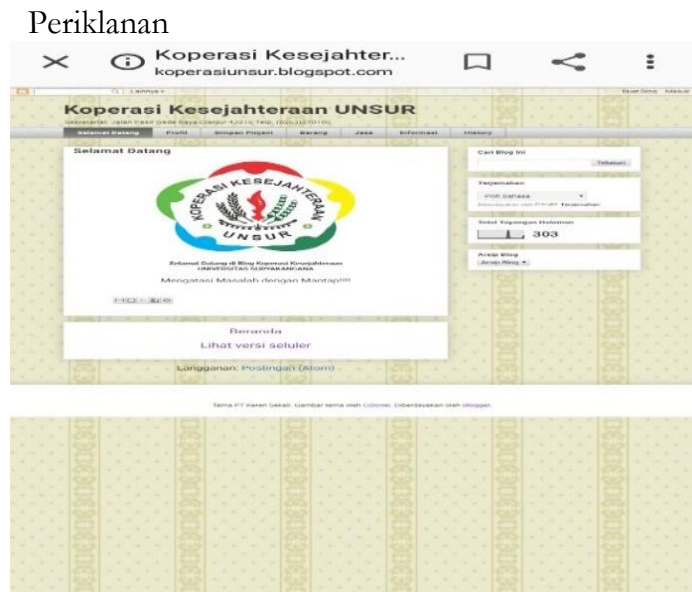

Gambar 6. Periklanan Menggunakan Media Sosial Blogspot.

\section{Pabrik Beras Sindang Asih}

Pabrik Beras Sindang Asih Cianjur memulai usaha pada tahun 1970, dengan founder yang lebih dari 30 tahun telah berpengalaman dalam dunia perberasan yang diketuai oleh Bapak Johan Harianto. Pabrik Sindang Asih beralamat di Jl. KH Shaleh No.168, Karangtengah Kabupaten Cianjur 43281.

Visi :

Produk yang dihasilkan oleh PB Sindang Asih berlandaskan nilai-nilai keamaan pangan dan kepuasa pelanggan serta terbaik dari segi kualitas dan harga.

Misi :

1. Senantiasa menjaga ketersediaan bahan olahan (padi/malai, beras) dengan cara menjalin kemitraan dengan petani serta penyalur beras dari dalam dan luar daerah.

2. Senantiasa menjaga kualitas hasil olahan dengan langkah kontrol kualitas (Quality Control) secara berjenjang dari
Kesejahteraan

Suryakancana

Media komunikasi pemasaran yang telah digunakan oleh Koperasi Kesejahteraan UNSUR diantaranya :

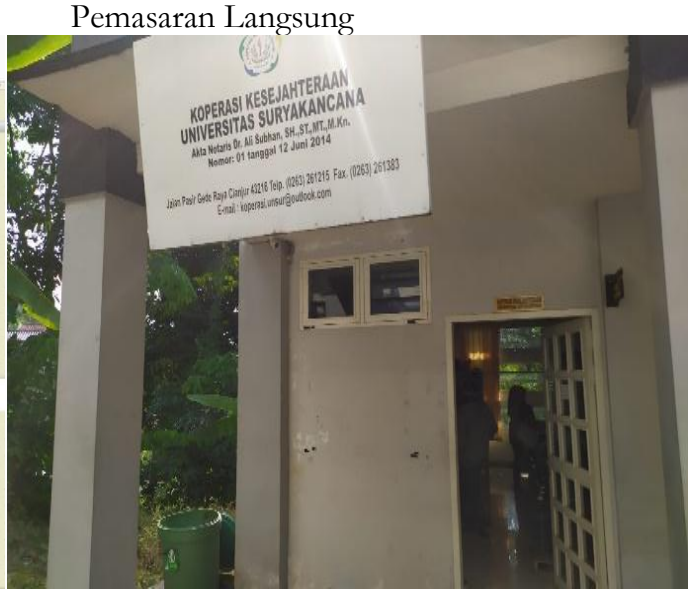

Gambar 7. Pemasaran Langsung.

mulai kedatangan bahan sampai dengan pengemasan beras.

3. Senantiasa memberikan higienitas bahan, alat proses, serta tenaga pengolah (pegawai) dengan menerapkan peraturan yang ketat sesuai dengan rujukan kementerian Tenaga Kerja dan Badan Pengawas Obat dan Makanan.

4. Senantiasa memberikan pelayanan prima mulai dari proses pemesanan hingga mendistribusikan kepada pelanggan dengan prioritas ketepatan waktu serta tujuan.

Pabrik Sindang Asih sudah lebih dari 2 tahun telah memasarkan beras Pandanwangi dan telah terdaftar di MP3C yang telah memiliki izin legalitas untuk memasarkan beras Pandanwangi Tidak hanya beras Pandanwangi tetapi PB Sindang Asih pun memasarkan beras varietas lain. Beras Pandanwangi diperoleh dari para petani yang sudah bekerjasama yakni petani yang ada di 7 
kecamatan yang termasuk wilayah indiksasi geografis Cianjur tetapi paling banyak dipasok oleh petani dari kecamatan Warungkondang, Cilaku, Cibeber, dan Gekbrong.
Media komunikasi pemasaran yang telah digunakan oleh PB Sindang Asih di antaranya:



Gambar 8. Iklan berupa Pemasaran Menggunakan Media Sosial Facebook.

Pemasaran Langsung

Pemasaran langsung yang dilakukan oleh PB Sindang Asih konsumen secara langsung mendatangi tempat untuk membeli beras Pandanwangi. Wilayah pemasarannya pun tak hanya dari wilayah Cianjur adapun dari kota Bandung, Bogor dan Jakarta.

\section{Pabrik Beras OKH}

Pabrik Beras OKH diketuai oleh Bapak Hendra Atmaja, beralamat di Jl.
Raya Cianjur Sukabumi KM. 5 Desa Sirnagalih Kec. Cilaku Kabupaten Cianjur. Pabrik beras $\mathrm{OKH}$ telah menjual beras Pandanwangi selama 2 tahun terakhir dan telah mendapatkan izin rekomendasi penggunaan logo sertifikat indikasi geografis beras Pandanwangi yang telah terdaftar di MP3C.

Media komunikasi pemasaran yang telah digunakan oleh PB OKH diantaranya :

Periklanan
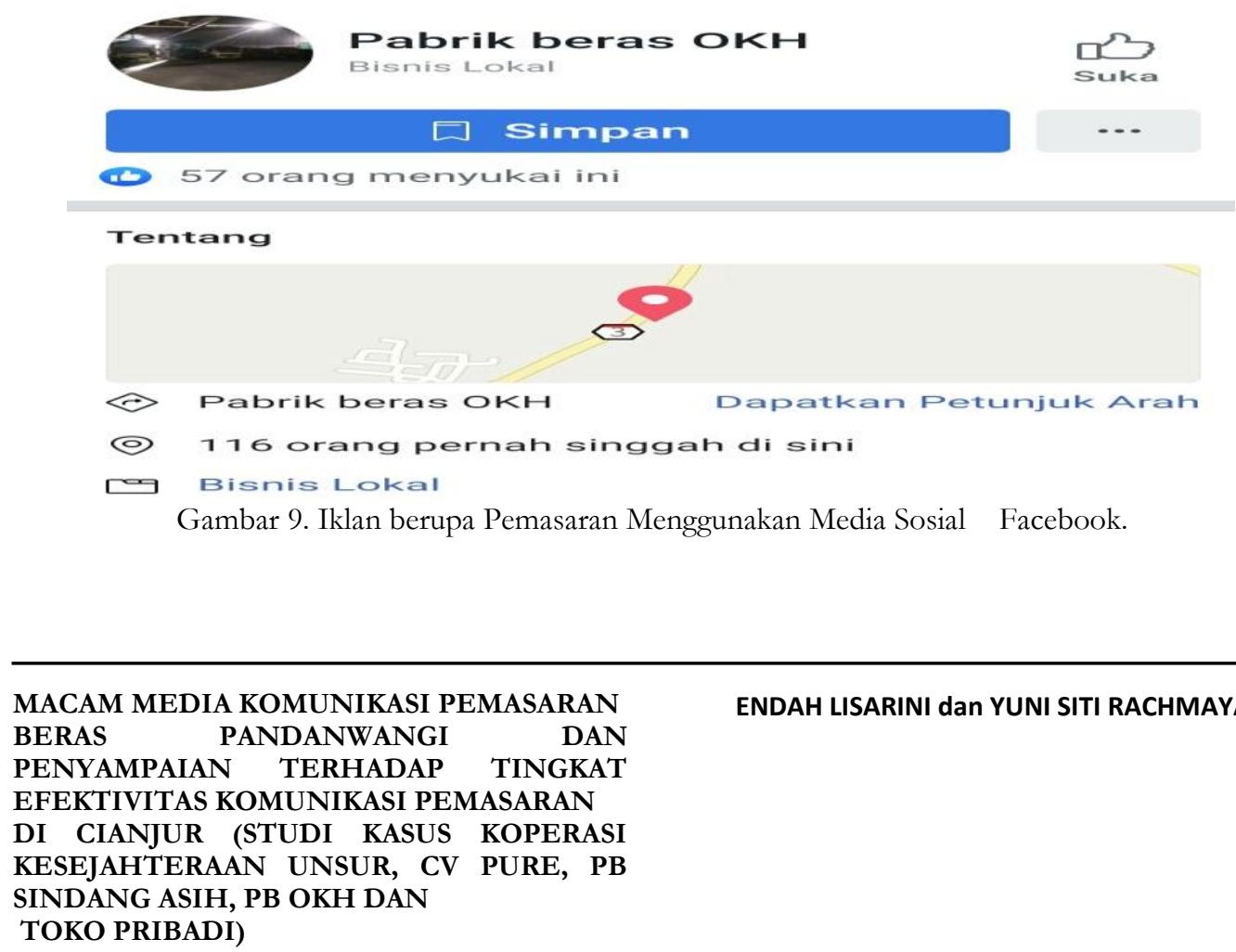
Pemasaran Langsung

$$
\text { Pemasaran langsung yang }
$$

dilakukan oleh PB. OKH yaitu konsumen dari Cianjur secara langsung mendatangi tempat untuk membeli beras Pandanwangi baik untuk dikonsumsi ataupun untuk diperjual belikan kembali. Target pemasarannya yaitu ke wilayah pemasaran Cianjur yang menjual beras Pandanwangi seperti di pusat oleh-oleh dimana konsumen dari luar Cianjur bisa membeli beras khas Cianjur yaitu beras Pandanwangi bisa didapatkan di pusat oleh-oleh yang tersedia di Cianjur.

\section{Toko Beras Pribadi}

Toko beras pribadi yang dimiliki oleh Bapak Indrawan Thopandi beralamat di Jl. Ir.H. Juanda No. 5, Panembong, Limbangansari, Kec. Cianjur, Kabupaten Cianjur, Jawa Barat 43211. Toko beras pribadi telah menjual beras Pandanwangi sejak tahun 1982 sampai saat ini. tidak hanya beras Pandanwangi tetapi toko beras pribadi pun menjual beras varietas lain.

Media komunikasi pemasaran yang telah digunakan oleh TB Pribadi diantaranya :

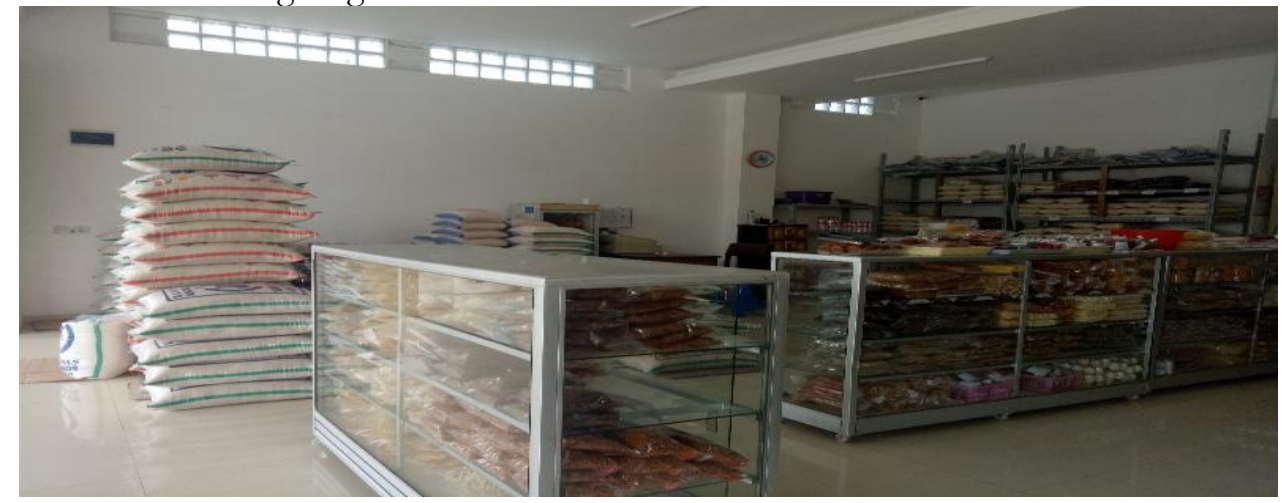

Gambar 10. Pemasaran Langsung Tb Pribadi.

\section{Karakteristik Konsumen}

Responden dalam penelitian ini, yaitu konsumen beras Pandanwangi yang pernah membeli di lima gerai yang dijadikan tempat penelitian yang berjumlah 50 orang. Karakteristik responden yang dimasukkan dalam penelitian ini yaitu jenis kelamin, usia, alamat, status pernikahan, tingkat pendidikan. Karakteristik responden diperlukan dalam penelitian ini karena karakteristik yang berbeda-beda dapat mempengaruhi penilaian responden. ( Damayanti,2010).

\section{Jenis Kelamin}

Jumlah responden berdasarkan jenis kelamin dapat dilihat pada tabel 3. di bawah ini.

Tabel 3.Jenis Kelamin Responden.

\begin{tabular}{clcc}
\hline No & \multicolumn{1}{c}{ Jenis Kelamin } & Jumlah Responden (orang) & Persentase (\%) \\
\hline 1 & Laki-laki & 17 & $34 \%$ \\
2 & Perempuan & 33 & $66 \%$ \\
3 & Total & 50 & $100 \%$ \\
\hline
\end{tabular}

Sumber : Data Primer, 2019 (data diolah).

Dari tabel di atas dapat Pandanwangi didominasi oleh perempuan disimpulkan bahwa konsumen beras sebanyak 33 orang dari 50 yang dijadikan 
sebagai responden atau sekitar 66\%, sedangkan laki-laki sebanyak 17 orang atau sekitar 34\%. Keadaan ini terjadi karena perempuan pada umumnya lebih berperan dalam urusan belanja rumah tangga dibandingkan laki-laki. Perempuan juga memiliki peran yang besar dalam proses pengambilan kepuasan pembelian kebutuhan sehari-hari, termasuk dalam mengkonsumsi beras.

\section{Usia}

Hasil penelitian berdasarkan sebaran umur, menunjukkan jumlah responden yang mengkonsumsi beras Pandanwangi didominasi oleh kelompok yang sudah cukup umur yaitu antara umur 20-30 tahun. Hal ini dapat dipahami karena pada umumnya konsumen yang berbelanja adalah konsumen yang berusia relative masih muda dan hal ini dapat dilihat pada gambar 4.1 bahwa responden yang berumur 20-30 tahun sebesar 48\% lebih banyak dibanding dengan kelompok lainnya yaitu sebesar $20 \%$ dan $6 \%$ berumur antara 41-50 dan $>50$ tahun, sebesar $26 \%$ oleh responden yang berumur 31-40 tahun.

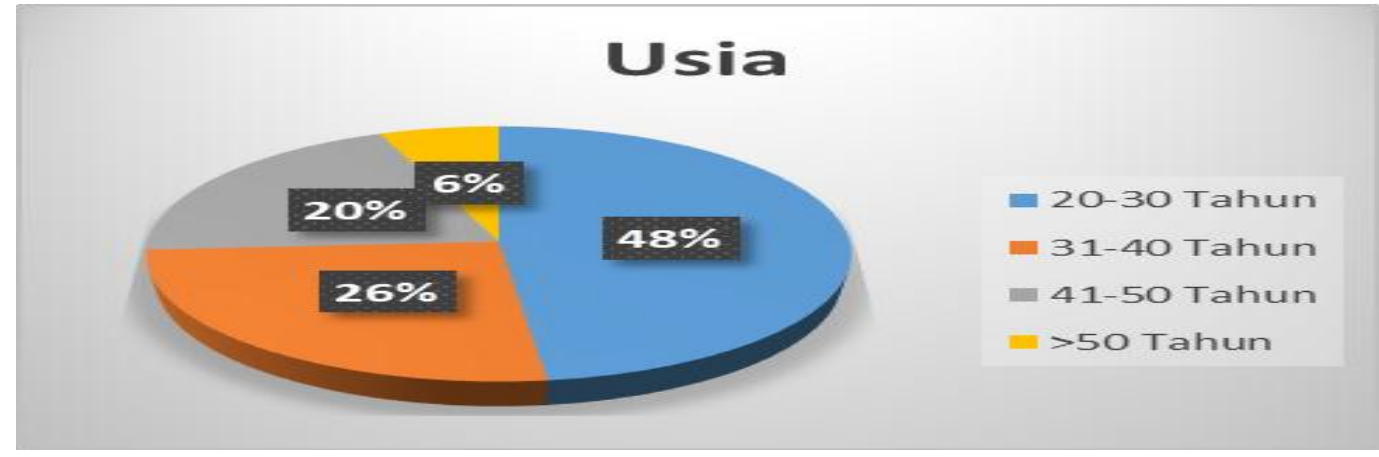

Gambar 11. Diagram Responden Berdasarkan Usia.

\section{Asal Daerah}

Dilihat dari gambar 12. di bawah bahwa dari sekian banyaknya responden beras Pandanwangi yang paling banyak yaitu dari Cianjur dengan jumlah 30 orang atau 60\%. Keadaan ini terjadi karena orang Cianjur lebih mudah untuk membeli dan bisa mendatangi langsung gerai-gerai / toko beras yang menjual beras Pandanwangi.

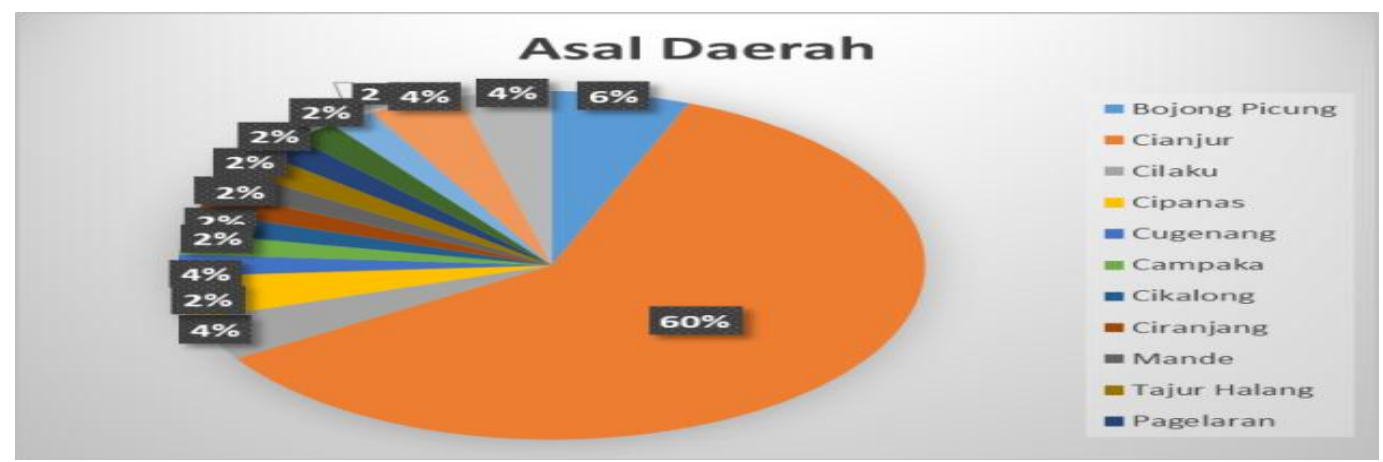

Gambar 12. Diagram Responden Berdasarkan Asal Daerah.

\section{Status Pernikahan Responden}

Berdasarkan kuesioner yang dibagikan pada 50 responden, diperoleh data mengenai status pernikahan responden seperti yang dapat dilihat pada gambar 13. di bawah ini. Jumlah antara responden yang telah menikah dan yang belum menikah dalam penelitian ini didominasi oleh responden yang sudah menikah.






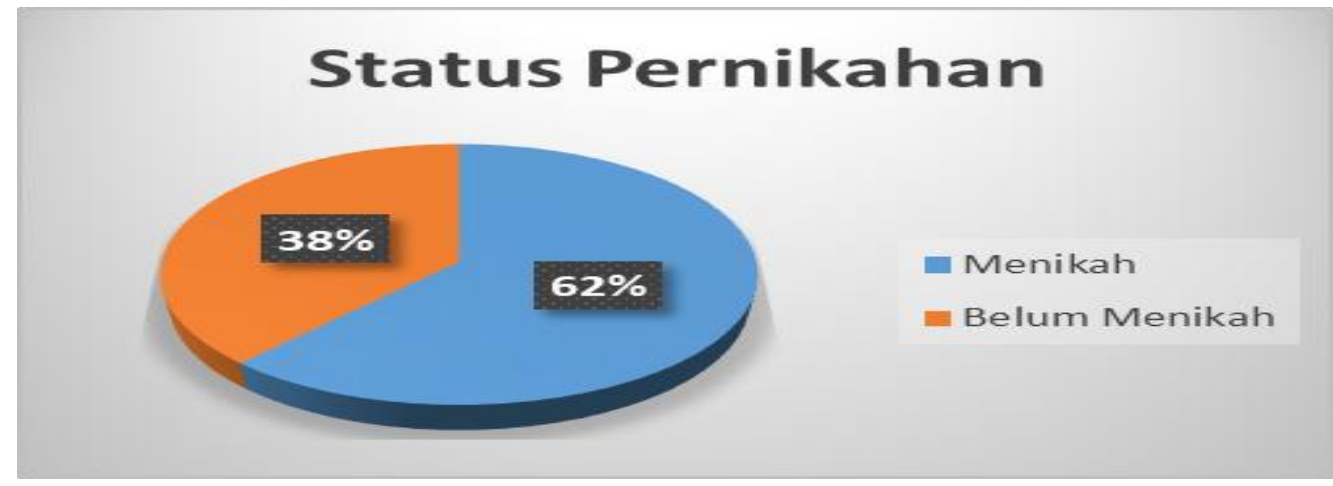

Gambar 13. Diagram Responden Berdasarkan Status Pernikahan.

Dari hasil penelitian menunjukkan bahwa konsumen beras Pandanwangi di Kabupaten Cianjur lebih banyak dari kalangan yang sudah menikah atau yang sudah mempunyai keluarga. Bagi seseorang yang sudah menikah, beras merupakan salah satu daftar belanja utama untuk memenuhi kebutuhan sehari-hari karena orang yang sudah mempunyai keluarga merupakan kelompok acuan primer yang paling berpengaruh terhadap sikap. Setiap anggota keluarga juga memegang peranan penting dalam pemberi pengaruh, pengambilan keputusan, pembelian dan pemakaian dan orang yang sudah menikah cenderung memperhatikan kualitas beras yang dibeli karena untuk kesehatan keluarganya.

\section{Tingkat Pendidikan Responden}

Dapat dilihat pada gambar 14 . bahwa tingkat pendidikan responden dalam penelitian ini yang paling banyak yaitu di tingkat perguruan tinggi sebanyak 35 orang atau sekitar $70 \%$, sedangkan responden dengan jenjang pendidikan SMA yaitu berjumlah 11 orang atau sekitar $22 \%$ dan responden yang dengan jenjang pendidikan SLTP berjumlah 1 orang atau sekitar $2 \%$, dan responden dengan jenjang pendidikan SD berjumlah 3 orang atau sekitar $6 \%$. Dapat dijelaskan bahwa konsumen dengan pendidikan yang tinggi akan mempengaruhi proses keputusan pembelian. Dengan pendidikan yang semakin tinggi, konsumen akan lebih cerdas dalam memilih produk yang dibeli seperti memilih membeli beras karena dengan tingkat pendidikan yang dimiliki, mereka lebih sadar terhadap mutu dan keamanan beras yang mereka konsumsi.



Gambar 14. Diagram Responden Berdasarkan Tingkat Responden. 


\section{Analisis Hasil Penelitian}

Untuk menjawab tujuan penelitian ini pertama, penulis melakukan observasi lapangan di sejumlah gerai-gerai/ toko beras, dan konsumen beras Pandanwangi Cianjur. Dari hasil observasi lapangan diperoleh informasi mengenai sejumlah media komunikasi pemasaran beras Pandanwangi yang digunakan.

Untuk menjawab penelitian kedua, penulis mengitung data tanggapan responden terhadap efektivitas semua media komunikasi pemasaran yang digunakan oleh para penjual beras Pandanwangi Cianjur. Data yang diperoleh dari 50 responden akan dianalisis secara deskriptif dengan : (1) Penskoran Nilai Rata-rata Berdasarkan Kategori, (2) Perangkingan Nilai Skor Rata-rata.

\section{Penskoran Nilai Rata-rata \\ Berdasarkan Kategori}

Untuk menentukan penskoran nilai rata-rata tanggapan responden. Data yang terhitung yaitu skor nilai dibagi jumlah responden. Hasil yang diperoleh dibandingkan dengan kategori nilai interval yaitu : 1) Sangat tidak setuju, (2) Tidak setuju, (3) Cukup setuju, (4) Setuju, (5) Sangat Setuju.

Nilai rata-rata responden dimasukkan ke dalam kelas interval, dimana rumus yang digunakan menurut Sudjana (2008) dalam Nasir (2017) adalah:

Interval kelas $\equiv$ nilai tertinggi- nilai terendah

\section{Jumlah kelas}

Interval nilai $=5-1 /$ jumlah kelas $=4-5$ $=0,8$

Dari rumus tersebut diperoleh besarnya kelas interval adalah 0,8 .

Keterangan $:$ nilai tertinggi $=5$

nilai terendah $=1$

jumlah kelas $=5$

Tabel 4.Kategori Nilai Interval

\begin{tabular}{cc}
\hline Nilai Interval & Kategori \\
\hline $1,00-1,80$ & Sangat tidak setuju \\
$1,80-2,60$ & Kurang setuju \\
$2,61-3,40$ & Cukup setuju \\
$3,41-4,20$ & Setuju \\
$4,21-5,00$ & Sangat setuju \\
\hline
\end{tabular}

2. Hasil Pengukuran Variabel Periklanan

Pengukuran variable periklanan yaitu untuk mengetahui apakah iklan merupakan media komunikasi yang direspon baik oleh konsumen pada pemasaran beras Pandanwangi. Hasil pengukuran tersebut dapat dilihat pada tabel 4.3 di bawah ini.

Berdasarkan perhitungan dari ratarata indikator dikemukakan bahwa perhitungan hasil jawaban responden pada sub variabel periklanan didapatkan jumlah keseluruhan dengan kategori setuju, dengan nilai rata-rata keseluruhan sebesar 4,02 (3,41 - 4,20). Sementara nilai tertinggi dari variabel periklanan dalam kategori sangat setuju didapatkan nilai rata-rata sebesar 4,40 $(4,21-5,00)$ bahwa melalui iklan konsumen tertarik pada beras Pandanwangi.

Hasil Nilai Keseluruhan Variabel Periklanan didapatkan nilai rata-rata sebesar 4,02. 
Tabel 5. Hasil Nilai Variabel Periklanan.

\begin{tabular}{clcccc}
\hline No & \multicolumn{2}{c}{ Variabel Periklanan } & Rata-rata & Nilai Interval & Kategori \\
\hline 1 & $\begin{array}{l}\text { Perhatian saya tertuju pada beras } \\
\text { Pandanwangi di iklan medsos. }\end{array}$ & 4,40 & $4,21-5,00$ & Sangat setuju \\
\hline 2 & $\begin{array}{l}\text { Iklan beras Pandanwangi di medsos } \\
\text { menarik perhatian saya. }\end{array}$ & 4,26 & $4,21-5,00$ & Sangat setuju \\
\hline 3 & $\begin{array}{l}\text { Saya tertarik pada beras Pandanwangi yang } \\
\text { diiklankan. }\end{array}$ & 4,34 & $4,21-5,00$ & Sangat setuju \\
\hline 4 & $\begin{array}{l}\text { Saya tertarik dengan produk beras } \\
\text { Pandanwangi karena iklan. }\end{array}$ & 4,02 & $3,41-4,20$ & Setuju \\
\hline 5 & $\begin{array}{l}\text { Iklan memenuhi keingintahuan saya } \\
\text { mengenai beras Pandanwangi. }\end{array}$ & 4,02 & $3,41-4,20$ & Setuju \\
\hline 6 & $\begin{array}{l}\text { Keingintahuan saya mengenai info beras } \\
\text { Pandanwangi dapat diperoleh melalui iklan. }\end{array}$ & 3,74 & $3,41-4,20$ & Setuju \\
\hline 7 & $\begin{array}{l}\text { Akhirnya saya memilih membeli beras } \\
\text { Pandanwangi karena iklan. }\end{array}$ & 3,64 & $3,41-4,20$ & Setuju \\
\hline 8 & $\begin{array}{l}\text { Iklan membuat saya membeli beras } \\
\text { Pandanwangi. }\end{array}$ & 3,74 & $3,41-4,20$ & Setuju \\
\hline & Nilai Rata-rata Keseluruhan & $\mathbf{4 , 0 2}$ & $\mathbf{3 , 4 1 - 4 , 2 0}$ & Setuju \\
\hline S
\end{tabular}

Sumber: Data primer, 2019.

\section{Hasil Pengukuran Variabel Penjualan Perseorangan}

Dari hasil tabel di atas pengukuran variabel penjualan perseorangan berdasarkan perhitungan dari setiap indikator dikemukakan bahwa, hasil keseluruhan jawaban responden didapat nilai rata-rata sebesar 4,03. Sementara nilai tertinggi dengan kategori setuju sebesar 4,14 (3,41 -4,20) Keadaan ini menjelaskan bahwa penjualan perseorangan memenuhi keingintahuan konsumen pada beras Pandanwangi.

Tabel 6. Hasil Nilai Interval Variabel Penjualan Perseorangan.

\begin{tabular}{clccc}
\hline No & \multicolumn{1}{c}{ Variabel Penjualan Perseorangan } & Rata-rata & Nilai Interval & Kategori \\
\hline 1 & $\begin{array}{l}\text { Penjualan perseorangan yang dilakukan pemilik } \\
\text { gerai beras Pandanwangi menarik perhatian. }\end{array}$ & 3,98 & $3,41-4,20$ & Setuju \\
\hline 2 & $\begin{array}{l}\text { Perhatian saya tertuju pada beras Pandanwangi } \\
\text { di penjualan perseorangan. }\end{array}$ & 4,06 & $3,41-4,20$ & Setuju \\
\hline 3 & $\begin{array}{l}\text { Penjualan perseorangan yang dilakukan oleh } \\
\text { pemilik gerai beras Pandanwangi membuat saya } \\
\text { tertarik. }\end{array}$ & 4,02 & $3,41-4,20$ & Setuju \\
\hline 4 & $\begin{array}{l}\text { Dengan penjualan perseorangan membuat saya } \\
\text { tertarik terhadap beras Pandanwangi. }\end{array}$ & 3,94 & $3,41-4,20$ & Setuju \\
\hline 5 & $\begin{array}{l}\text { Penjualan memenuhi } \\
\text { keingintahuan perseorangan } \\
\text { Pandanwangi. }\end{array}$ mengenai beras \\
\hline 6 & $\begin{array}{l}\text { Keingintahuan saya mengenai info beras } \\
\text { Pandanwangi dapat diperoleh melalui penjualan } \\
\text { perseorangan. }\end{array}$ & 3,88 & $3,41-4,20$ & Setuju \\
\hline $\begin{array}{l}\text { Akhirnya saya memilih membeli beras } \\
\text { Pandanwangi karena penjualan perseorangan }\end{array}$ & 4,06 & $3,41-4,20$ & Setuju \\
\hline 8 & $\begin{array}{l}\text { Penjualan perseorangan membuat saya membeli } \\
\text { beras Pandanwangi. }\end{array}$ & 4,12 & $3,41-4,20$ & Setuju \\
\hline
\end{tabular}

Sumber : Data primer, 2019. 
Hasil Nilai Keseluruhan Variabel

rata-rata sebesar 4,03

Penjualan perseorangan didapatkan nilai

4. Hasil Pengukuran Variabel Publisitas

Tabel 7. Hasil Nilai Interval Variabel Publisitas

\begin{tabular}{clccc}
\hline No & Variabel Publisitas & Rata-rata & Nilai Interval & Kategori \\
\hline 1 & $\begin{array}{l}\text { Publisitas yang dilakukan oleh pemilik gerai } \\
\text { beras Pandanwangi menarik perhatian saya. }\end{array}$ & 4,00 & $3,41-4,20$ & Setuju \\
2 & $\begin{array}{l}\text { Perhatian saya tertuju pada beras Pandanwangi } \\
\text { melalui publisitas. }\end{array}$ & 3,98 & $3,41-4,20$ & Setuju \\
& $\begin{array}{l}\text { Penjualan dalam publisitas yang dilakukan oleh } \\
\text { pemilik gerai beras Pandanwangi membuat saya } \\
\text { tertarik. }\end{array}$ & 3,98 & $3,41-4,20$ & Setuju \\
4 & $\begin{array}{l}\text { Saya tertarik produk beras Pandanwangi melalui } \\
\text { publisitas. }\end{array}$ & 4,10 & $3,41-4,20$ & Setuju \\
5 & $\begin{array}{l}\text { Publisitas memenuhi keingintahuan saya } \\
\text { mengenai beras Pandanwangi. }\end{array}$ & 3,90 & $3,41-4,20$ & Setuju \\
6 & $\begin{array}{l}\text { Keingintahuan saya mengenai info beras } \\
\text { Pandanwangi dapat diperoleh melalaui publisitas. } \\
\text { Akhirnya saya memilih membeli beras }\end{array}$ & 3,90 & $3,41-4,20$ & Setuju \\
$\begin{array}{l}\text { Pandanwangi karena publisitas. } \\
\text { Publisitas membuat saya membeli beras }\end{array}$ & 3,72 & $3,41-4,20$ & Setuju \\
\hline $\begin{array}{l}\text { Pandanwangi. } \\
\text { Nilai Rata-rata Keseluruhan }\end{array}$ & $\mathbf{3 , 9 3}$ & $\mathbf{3 , 4 1 - 4 , 2 0}$ & Setuju \\
\hline
\end{tabular}

Sumber : Data Primer, 2019.

Hasil Nilai Keseluruhan Variabel Publisitas didapatkan nilai rata-rata sebesar 3,9325

Berdasarkan perhitungan dari rata-rata indikator dikemukakan bahwa perhitungan hasil jawaban responden pada sub variabel publisitas didapatkan nilai skor rata-rata keseluruhan sebesar 3,93. Sementara skor tertinggi dari variabel publisitas dalam kategori setuju dengan nilai rata-rata sebesar 4,10 (3,41 $4,20)$ Keadaan ini menjelaskan bahwa publisitas membuat konsumen tertarik pada beras Pandanwangi. 


\section{Hasil Pengukuran Variabel Promosi Penjualan}

Tabel 8. Hasil Nilai Interval Variabel Promosi Penjualan.

\begin{tabular}{|c|c|c|c|c|}
\hline No & Variabel Promosi Penjualan & Rata-rata & Nilai Interval & Kategori \\
\hline 1 & $\begin{array}{l}\text { Promosi penjualan yang dilakukan oleh pemilik } \\
\text { gerai beras Pandanwangi menarik perhatian. }\end{array}$ & 3,88 & $3,41-4,20$ & Setuju \\
\hline 2 & $\begin{array}{l}\text { Perhatian saya tertuju pada beras Pandanwangi } \\
\text { di promosi penjualan. }\end{array}$ & 3,98 & $3,41-4,20$ & Setuju \\
\hline 3 & $\begin{array}{l}\text { Saya tertarik pada beras Pandanwangi melalui } \\
\text { promosi penjualan. }\end{array}$ & 3,92 & $3,41-4,20$ & Setuju \\
\hline 4 & $\begin{array}{l}\text { Saya tertarik dengan produk beras Pandanwangi } \\
\text { karena promosi penjualan. }\end{array}$ & 3,94 & $3,41-4,20$ & Setuju \\
\hline 5 & $\begin{array}{l}\text { Promosi penjualan memenuhi keingin tahuan } \\
\text { saya mengenai beras Pandanwangi. }\end{array}$ & 4,00 & $3,41-4,20$ & Setuju \\
\hline & Keingintahuan saya mengenai info beras & & & \\
\hline 6 & $\begin{array}{l}\text { Pandanwangi dapat diperoleh melalui promosi } \\
\text { penjulan. }\end{array}$ & 3,94 & $3,41-4,20$ & Setuju \\
\hline 7 & $\begin{array}{l}\text { Akhirnya saya memilih membeli beras } \\
\text { Pandanwangi karena promosi penjualan. }\end{array}$ & 3,92 & $3,41-4,20$ & Setuju \\
\hline 8 & $\begin{array}{l}\text { Promosi penjualan membuat saya membeli beras } \\
\text { Pandanwangi. }\end{array}$ & 3,98 & $3,41-4,20$ & Setuju \\
\hline & Nilai Rata-rata Keseluruhan & 3,95 & $3,41-4,20$ & Setuju \\
\hline
\end{tabular}

Sumber: Data Primer, 2019.

Hasil Nilai Keseluruhan Variabel Promosi Penjualan didapatkan nilai ratarata sebesar 3,95.

Berdasarkan perhitungan dari ratarata indikator dikemukakan bahwa perhitungan hasil jawaban responden pada sub variabel promosi penjualan didapat skor keseluruhan sebesar 3,95.
Sementara skor tertinggi dari variabel publisitas dalam kategori setuju dengan nilai rata-rata yang sama sebesar 4,00 (3,41 - 4,20) Keadaan ini menjelaskan bahwa melalui promosi penjualan memenuhi keingin tahuan saya mengenai beras Pandanwangi.

\section{Hasil Pengukuran Variabel Pemasaran Langsung}

Tabel 9. Hasil Nilai Interval Variabel Pemasaran Langsung.

\begin{tabular}{|c|c|c|c|c|}
\hline No & Variabel Pemasaran Langsung & Rata-rata & Nilai Interval & Kategori \\
\hline 1 & $\begin{array}{l}\text { Pemasaran langsung menarik perhatian saya } \\
\text { terhadap beras Pandanwangi. }\end{array}$ & 4,14 & $3,41-4,20$ & Setuju \\
\hline 2 & $\begin{array}{l}\text { Perhatian saya tertuju pada beras Pandanwangi di } \\
\text { pemasaran langsung. }\end{array}$ & 4,10 & $3,41-4,20$ & Setuju \\
\hline 3 & $\begin{array}{l}\text { Saya tertarik pada beras Pandanwangi melalui } \\
\text { pemasaran langsung. }\end{array}$ & 4,12 & $3,41-4,20$ & Setuju \\
\hline 4 & $\begin{array}{l}\text { Saya tertarik dengan produk beras Pandanwangi } \\
\text { karena pemasaran langsung. }\end{array}$ & 4,02 & $3,41-4,20$ & Setuju \\
\hline 5 & $\begin{array}{l}\text { Pemasaran langsung memenuhi keingintahuan saya } \\
\text { mengenai beras Pandanwangi. }\end{array}$ & 4,18 & $3,41-4,20$ & Setuju \\
\hline & Keingintahuan saya mengenai info beras & & & \\
\hline 6 & $\begin{array}{l}\text { Pandanwangi dapat diperoleh melalui pemasaran } \\
\text { langsung. }\end{array}$ & 4,20 & $3,41-4,20$ & Setuju \\
\hline 7 & $\begin{array}{l}\text { Akhirnya saya memilih membeli beras } \\
\text { Pandanwangi karena pemasaran langsung. }\end{array}$ & 3,98 & $3,41-4,20$ & Setuju \\
\hline 8 & $\begin{array}{l}\text { Pemasaran langsung membuat saya membeli beras } \\
\text { Pandanwangi. }\end{array}$ & 4,08 & $3,41-4,20$ & Setuju \\
\hline & Nilai Rata- rata Keseluruhan & 4,10 & $3,41-4,20$ & Setuju \\
\hline
\end{tabular}


Hasil Nilai Keseluruhan Variabel Pemasaran Langsung didapatkan nilai rata-rata sebesar 4,10.

Tabel di atas menunjukkan bahwa variabel tingkat pemasaran langsung pada media komunikasi pemasaran beras Pandanwangi memiliki nilai keseluruhan rata-rata yaitu sebesar 4,10. Sementara skor tertinggi media komunikasi pemasaran langsung dengan kategori responden setuju dengan nilai rata-rata sebesar 4,20 (3,41 - 4,20) bahwa pemasaran langsung membuat keingintahuan konsumen mengenai info beras Pandanwangi.

Tabel 10. Jawaban Hasil Skor Nilai Rata-rata Tanggapan Responden

\begin{tabular}{ccc}
\hline No & Variabel & Rata-rata \\
\hline 1. & Periklanan & 4,02 \\
2. & Penjualan perseorangan & 4,03 \\
3. & Publisitas & 3,93 \\
4. & Promosi penjualan & 3,95 \\
5. & Pemasaran langsung & 4,10 \\
\hline
\end{tabular}

Bahwa dari hasil tabel diatas media komunikasi pemasaran yang efektif dalam menyampaikan informasi kepada konsumen mengenai beras Pandanwangi yaitu variabel pemasaran langsung dengan nilai rata-rata keseluruhan sebesar 4,10 $(3,41-4,20) \quad$ dalam kategori setuju.

\section{Perangkingan Skor Nilai Rata-rata}

Dari butir pernyataan diperoleh skor nilai rata-rata tanggapan responden.Untuk melihat tingkat efektivitas penyampaian pesan pemasaran melalui berbagai media komunikasi pemasaran, dilakukan perangkingan skor rata-rata tanggapan konsumen sebagai berikut :

Tabel 11. Hasil Perangkingan Skor Nilai Rata-rata Tanggapan Responden.

\begin{tabular}{|c|c|c|c|c|}
\hline No & Butir Pernyataan & $\begin{array}{c}\text { Rata- } \\
\text { rata }\end{array}$ & $\begin{array}{c}\text { Nilai } \\
\text { Interval }\end{array}$ & Kategori \\
\hline 1 & $\begin{array}{l}\text { Perhatian saya tertuju pada beras Pandanwangi di iklan } \\
\text { medsos }\end{array}$ & 4,40 & $\begin{array}{c}4,21- \\
5,00\end{array}$ & $\begin{array}{l}\text { Sangat } \\
\text { Setuju }\end{array}$ \\
\hline 2 & Saya tertarik pada beras Pandanwangi yang diiklankan. & 4,34 & $\begin{array}{c}4,21- \\
5,00\end{array}$ & $\begin{array}{l}\text { Sangat } \\
\text { Setuju }\end{array}$ \\
\hline 3 & $\begin{array}{l}\text { Iklan beras Pandanwangi di medsos menarik perhatian } \\
\text { saya. }\end{array}$ & 4,26 & $\begin{array}{c}4,21- \\
5,00\end{array}$ & $\begin{array}{l}\text { Sangat } \\
\text { Setuju }\end{array}$ \\
\hline 4 & $\begin{array}{l}\text { Keingintahuan saya mengenai info beras Pandanwangi } \\
\text { dapat diperoleh melalui pemasaran langsung. }\end{array}$ & 4,20 & $\begin{array}{c}3,41- \\
4,20\end{array}$ & Setuju \\
\hline 5 & $\begin{array}{l}\text { Pemasaran langsung memenuhi keingintahuan saya } \\
\text { mengenai beras Pandanwangi. }\end{array}$ & 4,18 & $\begin{array}{c}3,41- \\
4,20\end{array}$ & Setuju \\
\hline 6 & $\begin{array}{l}\text { Penjualan perseorangan memenuhi keingintahuan saya } \\
\text { mengenai beras Pandanwangi. }\end{array}$ & 4,14 & $\begin{array}{c}3,41- \\
4,20\end{array}$ & Setuju \\
\hline 7 & $\begin{array}{l}\text { Pemasaran langsung menarik perhatian saya terhadap } \\
\text { beras Pandanwangi }\end{array}$ & 4,14 & $\begin{array}{c}3,41- \\
4,20\end{array}$ & Setuju \\
\hline 8 & $\begin{array}{l}\text { Penjualan perseorangan membuat saya membeli beras } \\
\text { Pandanwangi. }\end{array}$ & 4,12 & $\begin{array}{c}3,41- \\
4,20\end{array}$ & Setuju \\
\hline 9 & $\begin{array}{l}\text { Saya tertarik pada beras Pandanwangi melalui pemasaran } \\
\text { langsung. }\end{array}$ & 4,12 & $\begin{array}{c}3,41- \\
4,20\end{array}$ & Setuju \\
\hline 10 & Saya tertarik produk beras Pandanwangi melalui publisitas. & 4,10 & $\begin{array}{c}3,41- \\
4,20\end{array}$ & Setuju \\
\hline 11 & $\begin{array}{l}\text { Perhatian saya tertuju pada beras Pandanwangi di } \\
\text { pemasaran langsung. }\end{array}$ & 4,10 & $\begin{array}{c}3,41- \\
4,20\end{array}$ & Setuju \\
\hline
\end{tabular}






\begin{tabular}{|c|c|c|c|c|}
\hline No & Butir Pernyataan & $\begin{array}{c}\text { Rata- } \\
\text { rata }\end{array}$ & $\begin{array}{c}\text { Nilai } \\
\text { Interval }\end{array}$ & Kategori \\
\hline 12 & $\begin{array}{l}\text { Pemasaran langsung membuat saya membeli beras } \\
\text { Pandanwangi }\end{array}$ & 4,08 & $\begin{array}{c}3,41- \\
4,20\end{array}$ & Setuju \\
\hline 13 & $\begin{array}{l}\text { Perhatian saya tertuju pada beras Pandanwangi di } \\
\text { penjualan perseorangan. }\end{array}$ & 4,06 & $\begin{array}{c}3,41- \\
4,20\end{array}$ & Setuju \\
\hline 14 & $\begin{array}{l}\text { Akhirnya saya memilih membeli beras Pandanwangi } \\
\text { karena penjualan perseorangan }\end{array}$ & 4,06 & $\begin{array}{c}3,41- \\
4,20\end{array}$ & Setuju \\
\hline 15 & $\begin{array}{l}\text { Saya tertarik dengan produk beras Pandanwangi karena } \\
\text { iklan. }\end{array}$ & 4,02 & $\begin{array}{c}3,41- \\
4,20\end{array}$ & Setuju \\
\hline 16 & $\begin{array}{l}\text { Iklan memenuhi keingintahuan saya mengenai beras } \\
\text { Pandanwangi. }\end{array}$ & 4,02 & $\begin{array}{c}3,41- \\
4,20\end{array}$ & Setuju \\
\hline 17 & $\begin{array}{l}\text { Penjualan perseorangan yang dilakukan oleh pemilik gerai } \\
\text { beras Pandanwangi membuat saya tertarik. }\end{array}$ & 4,02 & $\begin{array}{c}3,41- \\
4,20\end{array}$ & Setuju \\
\hline 18 & $\begin{array}{l}\text { Saya tertarik dengan produk beras Pandanwangi karena } \\
\text { pemasaran langsung. }\end{array}$ & 4,02 & $\begin{array}{c}3,41- \\
4,20\end{array}$ & Setuju \\
\hline 19 & $\begin{array}{l}\text { Publisitas yang dilakukan oleh pemilik gerai beras } \\
\text { Pandanwangi menarik perhatian saya. }\end{array}$ & 4,00 & $\begin{array}{c}3,41- \\
4,20\end{array}$ & Setuju \\
\hline 20 & $\begin{array}{l}\text { Promosi penjualan memenuhi keingin tahuan saya } \\
\text { mengenai beras Pandanwangi. }\end{array}$ & 4,00 & $\begin{array}{c}3,41- \\
4,20\end{array}$ & Setuju \\
\hline 21 & $\begin{array}{l}\text { Penjualan perseorangan yang dilakukan pemilik gerai beras } \\
\text { Pandanwangi menarik perhatian. }\end{array}$ & 3,98 & $\begin{array}{c}3,41- \\
4,20\end{array}$ & Setuju \\
\hline 22 & $\begin{array}{l}\text { Perhatian saya tertuju pada beras Pandanwangi melalui } \\
\text { publisitas. }\end{array}$ & 3,98 & $\begin{array}{l}3,41- \\
4,20\end{array}$ & Setuju \\
\hline 23 & $\begin{array}{l}\text { Penjualan dalam publisitas yang dilakukan oleh pemilik } \\
\text { gerai beras Pandanwangi membuat saya tertarik. }\end{array}$ & 3,98 & $\begin{array}{c}3,41- \\
4,20\end{array}$ & Setuju \\
\hline 24 & $\begin{array}{l}\text { Penjualan dalam publisitas yang dilakukan oleh pemilik } \\
\text { gerai beras Pandanwangi membuat saya tertarik. }\end{array}$ & 3,98 & $\begin{array}{c}3,41- \\
4,20\end{array}$ & Setuju \\
\hline 25 & $\begin{array}{l}\text { Perhatian saya tertuju pada beras Pandanwangi di promosi } \\
\text { penjualan. }\end{array}$ & 3,98 & $\begin{array}{c}3,41- \\
4,20\end{array}$ & Setuju \\
\hline 26 & $\begin{array}{l}\text { Akhirnya saya memilih membeli beras Pandanwangi } \\
\text { karena pemasaran langsung. }\end{array}$ & 3,98 & $\begin{array}{c}3,41- \\
4,20\end{array}$ & Setuju \\
\hline 27 & $\begin{array}{l}\text { Dengan penjualan perseorangan membuat saya tertarik } \\
\text { terhadap beras Pandanwangi. }\end{array}$ & 3,94 & $\begin{array}{c}3,41- \\
4,20\end{array}$ & Setuju \\
\hline 28 & $\begin{array}{l}\text { Saya tertarik dengan produk beras Pandanwangi karena } \\
\text { promosi penjualan. }\end{array}$ & 3,94 & $\begin{array}{l}3,41- \\
4,20\end{array}$ & Setuju \\
\hline 29 & $\begin{array}{l}\text { Keingintahuan saya mengenai info beras Pandanwangi } \\
\text { dapat diperoleh melalui promosi penjulan }\end{array}$ & 3,94 & $\begin{array}{l}3,41- \\
4,20\end{array}$ & Setuju \\
\hline 30 & $\begin{array}{l}\text { Saya tertarik pada beras Pandanwangi melalui promosi } \\
\text { penjualan. }\end{array}$ & 3,92 & $\begin{array}{c}3,41- \\
4,20\end{array}$ & Setuju \\
\hline 31 & $\begin{array}{l}\text { Akhirnya saya memilih membeli beras Pandanwangi } \\
\text { karena promosi penjualan. }\end{array}$ & 3,92 & $\begin{array}{c}3,41- \\
4,20\end{array}$ & Setuju \\
\hline 32 & $\begin{array}{l}\text { Publisitas memenuhi keingintahuan saya mengenai beras } \\
\text { Pandanwangi. }\end{array}$ & 3,90 & $\begin{array}{c}3,41- \\
4,20\end{array}$ & Setuju \\
\hline 33 & $\begin{array}{l}\text { Keingintahuan saya mengenai info beras Pandanwangi } \\
\text { dapat diperoleh melalaui publisitas. }\end{array}$ & 3,90 & $\begin{array}{c}3,41- \\
4,20\end{array}$ & Setuju \\
\hline 34 & $\begin{array}{l}\text { Keingintahuan saya mengenai info beras Pandanwangi } \\
\text { dapat diperoleh melalui penjualan perseorangan. }\end{array}$ & 3,88 & $\begin{array}{c}3,41- \\
4,20\end{array}$ & Setuju \\
\hline 35 & $\begin{array}{l}\text { Akhirnya saya memilih membeli beras Pandanwangi } \\
\text { karena publisitas. }\end{array}$ & 3,88 & $\begin{array}{c}3,41- \\
4,20\end{array}$ & Setuju \\
\hline
\end{tabular}




\begin{tabular}{llccc}
\hline No & \multicolumn{1}{c}{ Butir Pernyataan } & $\begin{array}{c}\text { Rata- } \\
\text { rata }\end{array}$ & $\begin{array}{c}\text { Nilai } \\
\text { Interval }\end{array}$ & Kategori \\
\hline \multirow{2}{*}{36} & $\begin{array}{l}\text { Promosi penjualan yang dilakukan oleh pemilik gerai beras } \\
\text { Pandanwangi menarik perhatian. }\end{array}$ & 3,88 & $\begin{array}{c}3,41- \\
4,20\end{array}$ & Setuju \\
\multirow{2}{*}{37} & $\begin{array}{l}\text { Keingintahuan saya mengenai info beras Pandanwangi } \\
\text { dapat diperoleh melalui iklan. }\end{array}$ & 3,74 & $\begin{array}{c}3,41- \\
4,20\end{array}$ & Setuju \\
\multirow{2}{*}{38} & Iklan membuat saya membeli beras Pandanwangi. & 3,74 & $\begin{array}{c}3,41- \\
4,20\end{array}$ & Setuju \\
\multirow{2}{*}{39} & Publisitas membuat saya membeli beras Pandanwangi & 3,72 & $\begin{array}{c}3,41- \\
4,20\end{array}$ & Setuju \\
\multirow{2}{*}{40} & $\begin{array}{l}\text { Akhirnya saya memilih membeli beras Pandanwangi } \\
\text { karena iklan. }\end{array}$ & 3,64 & $\begin{array}{c}3,41- \\
4,20\end{array}$ & Setuju \\
\hline
\end{tabular}

Sumber : Data Primer, 2019.

Dari tabel di atas dapat diketahui bahwa variabel nilai skor tertinggi yang jatuh di kategori sangat setuju yaitu ada 3 butir pernyataan yaitu pada variabel periklanan diantaranya:

Skor tertinggi pertama dengan nilai rata-rata sebesar 4,40 $(4,21-5,00)$ dalam kategori sangat setuju bahwa melalui iklan membuat tertarik perhatian konsumen terhadap beras Pandanwangi. Selanjutnya skor tertinggi ke dua dengan rata-rata sebesar 4,34 $(4,21-5,00)$ dalam kategori sangat setuju bahwa konsumen tertarik pada beras Pandanwangi yang diiklankan. Dan skor tertinggi ke tiga dengan ratarata sebesar 4,26 (4,21 - 5,00) dalam kategori sangat setuju bahwa iklan di medsos menarik perhatian konsumen terhadap beras Pandanwangi.

\section{KESIMPULAN}

Berdasarkan hasil pembahasan di atas maka dapat disimpulkan hal-hal sebagai berikut:

1. Nilai rata-rata keseluruhan tertinggi didapatkan dari media komunikasi pemasaran langsung sebesar 4,10 (3,41 - 4,20) dalam kategori setuju. Itu adalah media komunikasi pemasaran yang paling direspon oleh konsumen.

2. Tingkat efektivitas media komunikasi pemasaran dapat diketahui dari indikator tingkat efektivitas yang sangat direspon positif atau sangat setuju pada butir media komunikasi periklanan dengan butir pernyataan:

1)Perhatian saya tertuju pada beras Pandanwangi di iklan medsos, sebesar 4,40 (4,21 - 5,00)

2)Saya tertarik pada beras Pandanwangi yang diiklankan, sebesar 4,34 (4,21-5,00)

3)Iklan beras Pandanwangi di medsos menarik perhatian saya, sebesar 4,26 $4,21-5,00$

\section{DAFTAR PUSTAKA}

Abdul, 2016 . Analisis Efektivitas Komunikasi Pemasaran Pada Produk Yogurt Sentulfresh Indonesia Melalui Website. $\quad$ Bogor. file:///C:/Users/USER/Downloa ds/Jurnal $\% 20 I P B \% 202$.pdf diakses tanggal 22 April 2019.

Araujo, Magdalena De dan Nubatonis Agustinus. 2016. Analisis Produksi dan Pemasaran Usahatani Padi Sawah di Desa Tualene Kecamatan Biboki Utara Kabupaten Timor Tengah Utara. NTT.http://fapertaunimor.id/savanacendana.id/index.php/AG/article/ view/262/142. diakses tanggal 3 Januari 2019

Arikunto, S. 2006. Metode Penelitian Kualitatif. Jakarta: Bumi Aksara.

A Setiadi, 2016, Pemanfaatan Media Sosial Untuk. Efektifitas Komunikas Jl. Banten 
No. 1 Karangpawitan, Karawang . http://eprints.umm.ac.id/35140/3 Liptummpp-gdl-rimaikahan-472123-babii.pdf 11 April

A, Shimp, Terence. 2000. Periklanan Promosi: Aspek Tambahan Komunikasi Pemasaran Terpadu, edisi ke-5. Jakarta: Erlangga.

A, Shimp, Terence (2003). Periklanan Promosi \& Aspek Tambahan Komunikasi Pemasaran.Terpadu, Jilid I ( edisi 5), Jakarta: Erlangga.

Basu Swastha. 2009. Manajemen Penualan. Yogyakara: BPFE

Basu Swastha dan Irawan, 2006, Manajemen Pemasaran Modern, Liberty, Yogyakarta.

Belch, G.E and M.A. Belch. 2004. Advertising And Promotion: An Integrated Marketing Commnunications Perspective, Sixth Edition, The McGraw Hill/Irwin: New York.

Belch, George dan Belch, Michael. 2009. Advertising and Promotion: An Integrated Marketing Communication Perspective. New York: McGraw Hill.

Budiarto, S. 2011. Pemasaran Industri. Andi, Yogyakarta.

Chrismardani, Yustina. 2014. Komunikasi Pemasaran Terpadu Implementasi Untuk UMKM. Madura. http://kompetensi.trunojoyo.ac.id/ neo-bis/article/view/472 diakses tanggal 3 Januari 2019.

Damayanti, M. 2010. Komunikasi Terapeutik dalam Praktik Keperawatan. PT. Refika Aditama : Bandung.

Eddy Prasetyo, 2013, Pengaruh Iklan, Promosi Penjualan Dan Penjualan Perorangan Terhadap Niat Beli Di Cv. Lancar Makmur Motor Surakarta Universitas Kristen Petra Jl. Siwalankerto 121-131, Surabaya volume 1, No. 3, http://publication.petra.ac.id/index .php/manajemen- bisnis/article/view/1128 diakses tanggal 25 Mei 2019

eJournal Ilmu Komunikasi, Volume 5, Nomor 1, 2017: 13-23 hal:14 Pengaruh pelanggaran Etika Periklanan Pada Iklan Avian versi Awas Cat Basah Terhadap Presepsi Khalayak (Survey pada Masyarakat Keluruban Prenggan, Kecamatan Kotagede Yogyakarta).Yogyakarta. http://p3ipusat.com/buku-pedomanhimpunan-peraturan-etikaperiklanan-3 diakses tanggal 28 Maret 2019

Gita Permatasari , 2016, Efektivitas Media Sosial Instagram Sebagai Media Promosi Produk Olahan Pertanian "Yoghurt Cimory” Bogor. file:///C:/Users/USER/Downloa ds/Jurnal $\% 20 I P B . p d f \quad$ diakses tanggal 26 Mei 2019

Hadikusumah, KH. 2015. Deskripsi Pengambilan Keputusan Dalam Berusahatani. Cianjur. Https://Journal.Uinsgd.Ac.Id/Inde x.Php/Istek/Article/Download/24 $6 / 260$ diakses tanggal 2 januari 2019.

Hidayati, Dwi Ratna. 2016. Strategi Komunikasi Pemasaran Usaha Skala Mikero (Mikero Enterprise) Kub Bajrab Gunah Klampis Bangkalan Pada Produk Terasi, Petis, Dan Kerupuk Ikan.Madura.www.academia.edu/... /STRATEGI_KOMUNIKASI_PE MASARAN_USAHA_SKALA, diakses tanggal 2 Januari 2019

Hurriyati R. 2008. Bauran Pemasaran dan Loyalitas Konsumen. Bandung [ID]: Erlangga. 375 hal.

Iriani,Setyo Sri. 2013. Pengaruh Promosi Penjualan Dan Penjualan Perseorangan Terhadap Keputusan Belanja Tidak. Terencana . Surabaya. volume 1,No.12 file:///C:/Users/USER/Downloa ds/3038-5208-1-PB.pdf diakses tanggal 13 Juni 2019 
Ismanto. 2017. Strategi Komuikasi Pemasaran Dalam Mempromosikan Produk Melalui Media Online ( Studi Deskriptif Kualitatif pada Distro Anime Maximono Yogyakarta)

Kasali, Rhenald, 2007, Manajemen periklanan, konsep dan aplikasinya di Indonesia

Kennedy, John. E; R Dermawan Soemanagara., 2006. Marketing Communication - Taktik dan Strategi. Jakarta. PT Buana Ilmu Populer (kelompok Gramedia)

Kotler dan Armstrong. 2008. dasar dasar pemasaran. Alih bahasa oleh Alexander Sindoro dan Tim Mark Plus. Jakarta: PT. Indeks Gramedia

Kotler, Philip. 2009. Marketing Mangement,11st Edition. Upper Saddle River, New Jersey: Pearson Education international

Kotler, Philip.2003. Manajemen Pemasaran. Edisi kesebelas, Jakarta: Indeks kelompok Gramedia.

Kusuma, Hendra. 2017. Analisis Pemasaran Jamur Merang Lembaga Mandiri Mengakar Masyarakat (Lm3) Agrina

Di Tanjong Paya Kecamatan Peusangan Kabupaten Bireuen.

Kusniadji, Suherman. 2016. Strategi Komunikasi Pemasaran Dalam Kegiatan Pemasaran

Produk Consumer Goods. Semarang. Https://Journal.Untar.Ac.Id/Index .Php/Komunikasi/Article/View/4

9/54 Diakses Tanggal 2 Januari 2019

Komariah, Nur. 2016. Efektivitas Komunikasi Pemasaran Pada

Makanan Jajanan (Street Food) Waroeng. Bogor. https://studylibid.com/doc/17161 7/efektivitas-komunikasipemasaran-pada-makanan Diakses Tanggal 22 April 2019

Lukitaningsih, Ambar. 2013. Iklan Yang Efektif Sebagai Strategi Komunikasi Pemasaran. Yogyakarta. https://media.neliti.com/media/pu blications / 23468-ID-iklan-yang

efektif- sebagai strategi-

komunikasi-pemasaran.pdf diakses tanggal 9 Juni 2018

Morissan. 2010. Periklanan, Komunikasi Pemasaran Terpadu. Bandung: Prenada Media Group.

MP3C. 2015. Buku Persyaratan Indikasi Geografis Beras Mandanwangi Cianjur. Cianjur. http://ebook.dgip.go.id/indikasigeografis/filemedia/BukuPersyaratan-IG-Beras-PandanWangi-Cianjur/mobile/index.html. Artikel Diambil, diakses tanggal 24 April 2018

Mahardika Putra, 2018. Efektivita Media Sosial Instagram Sebagai Media Komunikasi Pemasaran Yogyakarta. https://repository.usd.ac.id/31323 $\angle 2 / 142214197$ full.pdf diakses tanggal 26 Mei 2019

Maisya, Fitri. 2013. Pengaruh Periklanan, Promosi Penjualan Dan Hubungan MasyarakatTerbadap Keputusan Menabung Di Pt. Bank Negara Indonesia, Tbk. Cabang Bukittinggi. Padang. http://ejournal.unp.ac.id/students / index.php/mnj/article/view/146/1 33 diakses tanggal 2 Januari 2019

Mawarya, Zimri Remalya. 2013. Periklanan Dan Citra Merek Pengarubnya Terbadap Keputusan Pembelian Kendaraan Bermotor Yamaha. Manado. https://ejournal.unsrat.ac.id/index. $\mathrm{php} / \mathrm{emba} /$ article/view/1891/150 0 diakses tanggal 2 Januari 2019

Maulidia, Nenden. 2018. Tigkat Kesukaan Konsumen Pada Atribut Beras Pandanwangi Murni Cianjur. Cianjur.

Meyrin, Lenny dkk. 2014. Peranan Komunikasi Pemasaran Dalam Menigkatkan Minat Pengguna Iklan Di Hariankomentar Manado. Manado. https://media.neliti.com/media/pu blications /90796-ID-peranan-

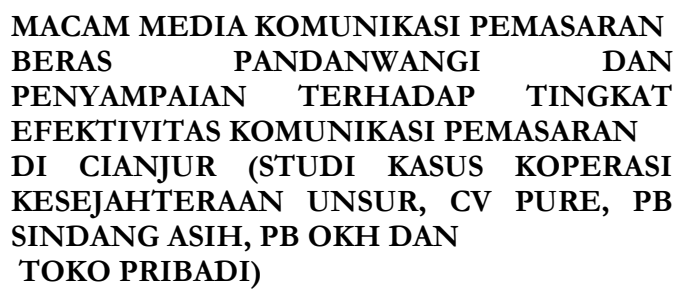


komunikasi-pemasaran-dalammenin.pdf diakses tanggal 18 Desember 2018

Muhibbin Syah.2010.Psikologi Pendidikan dengan pendekatan baru.Bandung:PT Remaja Rosdakarya

Muktiyo, Widodo Dkk. 2013. Manajemen Komunikasi Promosi dan Peemasaran. Pulau Lampauan: Surakarta

Mustdjab, Moch Muslich dkk. 2008. Analisis Pemasaran Beras Dalam Upaya Peningkatan Pendapatan Petani (Studi Kasus Pada Sentra Produksi Padi Di Desa Kayen, Kecamatan Kayen, Kabupaten Pati, Jawa Tengah). Jawa Tengah.https://agrise.ub.ac.id/inde x.php/agrise/article/view/7/8 diakses tanggal 29 Januari 2019.

Nuryana, I. (2017). Pengaruh Tingkat Kesehatan Bank terhadap Nilai Perusahaan dengan Profitabilitas sebagai Variabel Intervening (pada Bank Umum Swasta Nasional Periode 2011-2015). Seminar Nasional \& Call For Paper, FEB Unikama, 613-631.

Novi Claodya Lee. 2017. Pengarub Kualitas Produk Dan Periklanan Terhadap Keputusan Pembelian Teh Botol Sosro Kemasan Pet $450 \mathrm{Ml}$ (Studi Pada Pengunjung Minimarket Di Surabaya Selatan. Surabaya diakses tanggal 13 Juni 2019 volume 5, No.4.

Nency M. N. Togas, Jantje L. Sepang, Rudy S. Wenas. 2014. Periklanan, Penjualan Pribadi, Promosi Penjualan, Dan Publisitas Terbadap Keputusan Pembelian Pada Penerbit Andi Cabang Manado. Manado. Vol.2 No.4 Desember 2014, Hal. 578-588. 14 Juni 2019 http://www.journal.unair.ac.id/file rPDF/06 santi \%20Kewirausahaa n\%20 MKP .pdf diakses tanggal 25 Mei 2019

Philip Kotler dan Kevin L. Keller. 2006. Manajemen Pemasaran edisi ke 12 Jilid ke 1. New Jersey, Indeks
Priccila Natalia dan Mumuh Mulyana. 2014. Pengaruh Periklanan Dan Promosi Penjualan Terbadap Keputusan Pembelian Program Studi Manajemen, Sekolah Tinggi Imu Ekonomi Kesatuan - Bogor, Indonesia. file:///C:/Users/USER/Downloa ds $/ 13 \% 20-$ \%20JIMKES $\% 202014 \% 20 \mathrm{Vol} \% 20$ $2 \% 20 \mathrm{No}_{2} \% 202 \% 20$ Priccila $\% 20 \mathrm{Nat}$ alia $\% 20$ dan $\% 20$ Mumuh $\% 20$ Mulyan a.pdf diakses tanggal 25 Mei 2019

Rizqul, Akhmad K. 2012. Metode Pemasaran Kreatif Dengan Menggunakan Media Internet. Purbalingga.Https://Www.Academ ia.Edu/2711601/Metode_Pemasara n_Kreatif_

engan_Menggunakan_Media_Inter net diakses tanggal 2 Januari 2019

Rusma, Jimmy dkk. 2011. Kajian Preferensi Konsumen Rumah Tangga Terbadap Beras Organik Di Wilayah Kota Bogor. Bogor. http://jai.ipb.ac.id/index.php/jurn almpi/article/view/3773/2585 diakses tanggal 9 Juni 2018

Rangkuti F. 2009. Strategi Promosi yang Kreatif dan Analisis Kasus Integrated Marketing Communication. Jakarta (ID) : Gramedia Pustaka Utama. 286 Hal.

Sekaran, Uma. 2011. Jilid 1 Edisi Keempat. Research Method for Businees. Alih Bahasa: Kwan Men Yon. Jakarta: Salemba Empat.

Setyosari, Punaji. 2010. Metode Penelitian Penelitian dan Pengembangan. Jakarta: Kencana.

Solekhan dan Winarso,R. 2016. Pemanfaatan Media Sosial Sebagai Media Pemasaran Sangkar Burung Di Kabupaten Kudus. Kudus.https://jurnal.umk.ac.id/ind ex.php/SNA/article/view/683/69 5 diakses tanggal 17 Desember 2018

Sufa, F., dan Munas, B., Sufa, F. 2012. "Analisis Pengaruh Daya Tarik

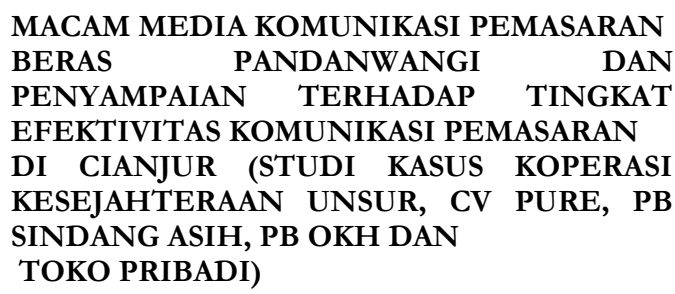

ENDAH LISARINI dan YUNI SITI RACHMAYANTI 
Iklan, Kualitas Pesan Iklan,

Frekuensi Penayangan Iklan terhadap Efektivitas Iklan Mie Sedap", Vol 1, Hal 226-233

Suardeyasasri. 2010. Metode Penelitian Kualitatif.

http://www.google.com/url?sa=t\& $\mathrm{rct}=\mathrm{j} \& \mathrm{q}=$ penelitian + metode + obser vasi+di+se

kolah\&source $=$ web\&cd $=3 \&$ cad $=$ rj a\&ved $=0$ CEIQFjAC\&url=http $\% 3$ $\mathrm{A} \% 2 \mathrm{~F} \% 2 \mathrm{~F}$

suardeyasasri.files.wordpress.com $\%$ 2F $2010 \% 2 \mathrm{~F} 02 \% 2 \mathrm{Fmetode}-$

penelitiankualitatif.pdf\&ei=50jvUP b4HYfIlQXB44Bg\&usg=AFQjCN Hpw2gbe8KKlsFa

1QVITxPqG1SjrA\&bvm=bv.13577

00187,d.bmk. diakses tanggal 29 Januari 2019.

Sugiyono. 2011. Metode Penelitian Kuantitatif dan Kualitatif dan $\mathrm{R} \& \mathrm{D}$. Bandung: CV Alfabeta.

Sugiyono. (2012). Metode Penelitian Kuantitatif Kualitatif dan R※D. Bandung: Alfabeta.

Sugiyono. 2013. Metode Penelitian Kuantitatif, Kualitatif dan R\&D. Bandung: Alfabeta.CV

Sugiyono. (2014). Metode Penelitian Pendidikan Pendekatan Kuantitatif, Kualitatif, dan R\&D. Bandung: Alfabeta.

Sukmadinata, Nana Syaodih, 2006. Metode Penelitian Pendidikan. Bandung: PT.Remaja Rosdakarya,cet kedua.

Sutisna. 2002. Perilaku Konsumen dan Komunikasi Pemasaran. PT Remaja Rosdakarya: Bandung
Sulaksana. 2003. Integrated Marketing Communications; Teks dan Kasus..Yogyakarta: Pustaka Pelajar.

S Dody Nugroho. 2014. Komunikasi Pemasaran Melalui Media Internet (ECommerce) Website Rumah Sakit ( Studi Deskriptif Kualitatif Komunikasi Pemasaran Melalui E- Commerce Website Rumah Sakit Dr. Oen Solo Baru).Yogyakarta.

Syifa Dewi Nuraeni, Bethani Suryawardani. 2017. Analisis Efektivitas Promosi Melalui Media Sosial Instagram Pada Pt.Niion Indonesia Utama, Prodi D3 Manajemen Pemasaran, Fakultas Ilmu Terapan, Universitas Telkom 25 Mei 2019.

Tjiptono. 2001. Manajemen Pemasaran dan Analisa Perilaku Konsumen, Yogyakarta: BPFE.

Tjiptono, Fandy. 2002. Strategi Pemasaran, Yogyakarta: Penerbit Andi

Tjiptono, Fandy. 2008. Strategi Pemasaran. Edisi tiga, Jakarta: Andi.

Umi Narimawati. 2008. Metodologi Penelitian Kualitatif dan Kuantitatif, Teori danAplikasi. Bandung: Agung Media.

Wurinanda I. 2015. Efektivitas promosi produk ayam suwir "si kentung" melalui twitter [skripsi]. Bogor (ID): Institut Pertanian Bogor.

Yola, Melfa dan Duwi Budianto. (2013). Analisis Kepuasan Konsumen Terhadap Kualitas Pelayanan Dan Harga Produk Pada Supermarket Dengan Menggunakan Metode Importance Performance Analysis (IPA). Jurnal Optimasi Sistem Industri. Vol. 12, No. 12, hlm. 